\title{
Collateral Damage? Micro-simulation of transaction cost shocks on the value of central bank collateral
}

\author{
This paper analyses how changes in \\ transaction costs may affect the value \\ of assets that banks use to collateralise \\ borrowings in monetary policy operations.
}

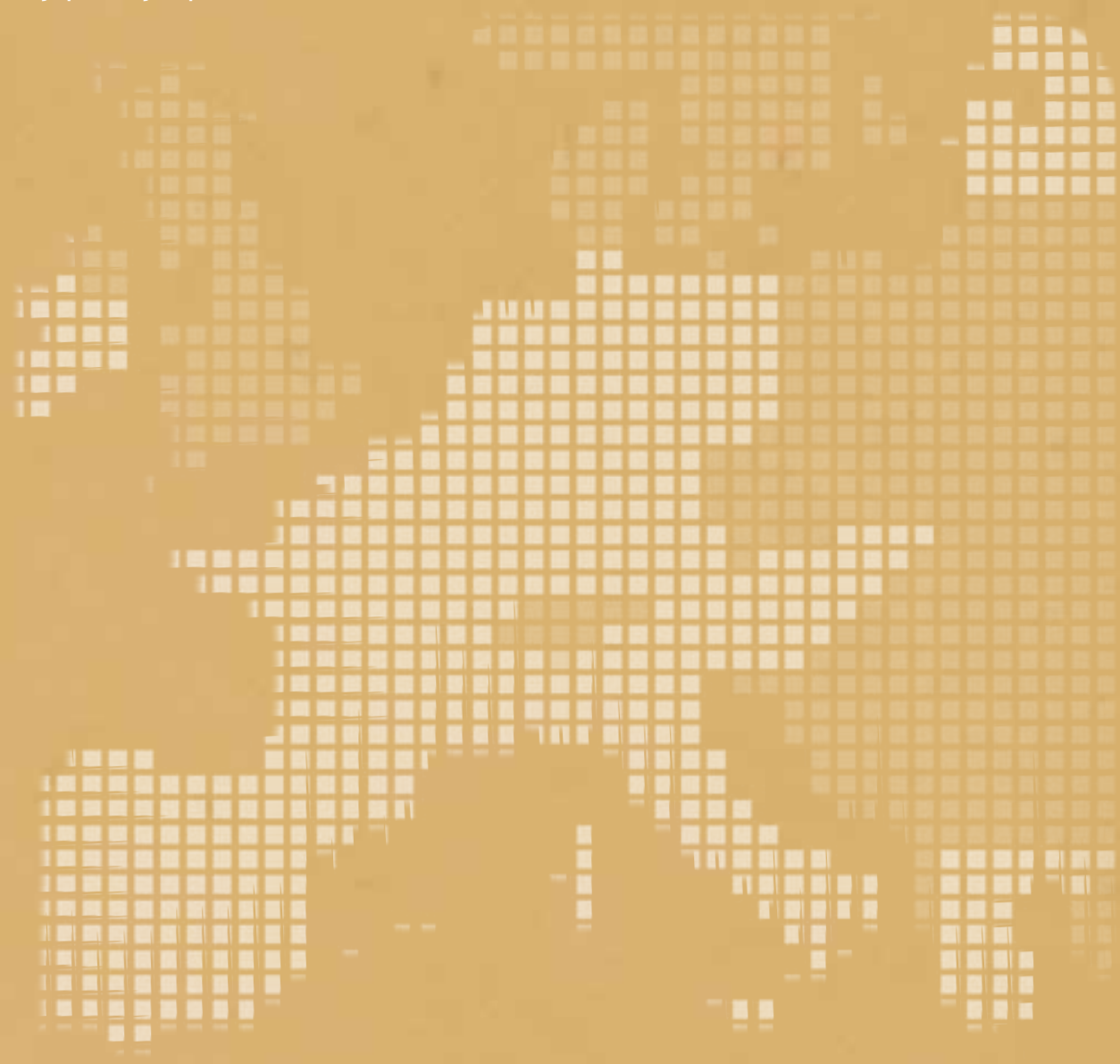

Rudolf Alvise Lennkh

European Stability Mechanism

Florian Walch

European Central Bank

European Stability Mechanism 


\title{
Collateral Damage? Micro-simulation of transaction cost shocks on the value of central bank collateral
}

\author{
Rudolf Alvise Lennkh ${ }^{1}$ \\ Florian Walch²
}

\begin{abstract}
Transaction cost shocks in financial markets are known to affect asset prices. This paper analyses how changes in transaction costs may affect the value of assets that banks use to collateralise borrowings in monetary policy operations. Based on a simple asset pricing model and employing a dataset of hypothetical Eurosystem collateral positions, we simulate and quantify the resulting change in collateral value pledged by counterparties to the Eurosystem, resulting from a transaction cost shock. A 10 basis point increase in transaction costs entails a direct $-0.30 \%$ decrease of collateral value and a $-0.07 \%$ decrease when adjusted for the expected reduction in the number of trades of each asset. We conclude that banks will on average suffer small collateral losses while selected institutions could face a considerably larger collateral decrease.
\end{abstract}

\section{Key words}

Transaction cost, collateral, central bank, monetary policy

JEL codes

C15, E59, G12

\footnotetext{
The authors would like to thank Benjamin Sahel, Peter Hofmann, Jean-Edouard Colliard, Eloi Espargilière, Miklos Vari, Miha Cajnko as well as anonymous referees and colleagues at the European Central Bank (ECB) for comments, suggestions and support.

${ }^{1}$ European Stability Mechanism, ra.lennkh@esm.europa.eu

${ }^{2}$ European Central Bank, florian.walch@ecb.europa.eu
}

\begin{abstract}
Disclaimer
This Working Paper should not be reported as representing the views of the ESM. The views expressed in this Working Paper are those of the author(s) and do not necessarily represent those of the ESM or ESM policy.

No responsibility or liability is accepted by the ESM in relation to the accuracy or completeness of the information, including any data sets, presented in this Working Paper.

The opinions expressed herein are those of the authors and do not necessarily reflect those of the European Central Bank or the Eurosystem.

(c) European Stability Mechanism, 2015 All rights reserved. Any reproduction, publication and reprint in the form of a different publication, whether printed or produced electronically, in whole or in part, is permitted only with the explicit written authorisation of the European Stability Mechanism.
\end{abstract}




\section{Introduction}

This paper analyses the consequences of a transaction cost shock on the value of assets that banking institutions submit as collateral to the central bank to obtain liquidity in monetary policy credit operations. Amidst the ongoing discussions about introducing some form of a financial transaction tax - be it EU-wide or in any other combination of European jurisdictions - this question is of particular interest to policymakers and central bankers. A change in transaction costs may require the central bank to adjust the implementation of its monetary policy in order to maintain its current policy stance under altered transmission conditions. Also other recent legislative proposals may affect transaction costs in financial markets. For example, the initiative for banking structural reform in the EU that follows up to the Liikanen report could have an impact on the cost of intermediation in the banking system as it could limit certain forms of market-making, depending on the outcome of the legislative process.

In its theoretical analysis, this paper disentangles the various channels through which transaction cost shocks may affect the value of the assets pledged by banks in their credit operations with the central bank. It explains how different assets will be affected by a transaction cost shock, depending on their turnover, maturity, coupon structure and other characteristics. Given these differences, central bank counterparties will also be affected heterogeneously, conditional on the collateral they dispose of. We then translate the theoretical findings into an asset-by-asset model of the Eurosystem collateral framework. To ensure confidentiality, we do not use the actual collateral positions of euro area banks. Instead, we construct a dataset of Eurosystem collateral, the most granular unit of observation of which are 12,000 assets drawn from the actual list of eligible assets. We allocate these to 1,800 hypothetical counterparties.

Micro-simulation is the methodology of choice to capture heterogeneous effects due to composition effects and characteristics on the micro level. More specifically, the model calculates how a transaction cost shock influences the required rate of return and consequently the market price for different assets. The calculation encompasses several scenarios resting on assumptions about the transaction cost shock and the size of second-round effects on trading volume. In our model, the first-round effect refers to the direct impact of the introduction of a transaction cost shock on the asset price, as determined by the sum of its discounted future cash flows, which declines by the present value of the transaction cost shock payable on all future transactions of a specific security. Second-round effects relate to the likely reduction in trading volume, which in turn reduces the negative impact of the first-round effect as the asset is less frequently traded. The model does not take into account general equilibrium effects beyond changes in trading volume.

The results of our simulations show that a 10-basis-point increase in transaction costs entails a $-0.30 \%$ decrease in collateral value without second-round effects. When including second-round effects on asset turnover of $25 \%$ or $75 \%$, the decrease in collateral value falls to $-0.22 \%$ and $0.07 \%$, respectively. The disaggregation of the results by asset characteristics shows that uncovered bank bonds, central government debt instruments, and bonds of non-financial corporates experience the largest decreases at $-0.96 \%,-0.91 \%$ and $-0.34 \%$, respectively, excluding secondround effects. We also find that residual maturities of 3-to-5 years and 1-to-3 years are more affected $(-0.49 \%$ and $-0.38 \%)$ than shorter and longer residual maturities. When differentiating between haircut buckets, the results show that the haircut category from $5 \%$ to $15 \%$ is affected 
the most at $-0.77 \%$. On the counterparty level, our study shows that counterparties with small and large collateral pools are similarly affected.

Overall, the vast majority of counterparties only experience a small collateral loss from a positive transaction cost shock, although some selected counterparties may suffer larger collateral losses. A counterparty with a low collateral buffer that is also collateral-constrained may either tolerate the increased risk of affording a smaller collateral buffer, post additional collateral if available, or reduce its outstanding liquidity position vis-à-vis the Eurosystem. From a policy perspective, assuming counterparties hit their collateral constraint as a result of the transaction cost shock, a small increase in the list of eligible securities for monetary policy operations or a reduction in the applied haircuts could be enough to compensate the shock. Thus, even if on average the counterparties' collateral buffer is large enough to absorb a transaction cost shock the shock is not costless.

\section{Theory and prior literature}

In order to implement their monetary policy stance central banks conduct monetary policy operations that can be carried out as outright purchases and sales or as credit operations. For outright purchases central banks acquire assets to hold them for an indeterminate period of time. Examples of such outright purchases or sales are the Securities and Market Programme (SMP), the Outright Monetary Transactions (OMTs), the Covered Bond Purchase Programmes (CBPPs), the Asset-backed Securities Purchase Programme (ABSPP) ${ }^{1}$ and the Public Sector Purchase Programme (PSPP) of the Eurosystem as well as the permanent open market operations conducted by the US Federal Reserve System (US Fed). In credit operations, by contrast, central banks lend (or borrow) funds to (from) a specified set of counterparties in exchange for eligible collateral assets based on (reverse) repurchase agreements or collateralised loans. Examples of such credit operations are the main refinancing operations or the long-term operations of the Eurosystem as well as the temporary open market operations and the discount window lending programme of the US Fed. Typically, the assets submitted as collateral are marked to market on a daily basis to ensure that the central bank is appropriately covered against financial risk. In addition, the actual central bank liquidity provided is less than the collateral that is pledged by counterparties, given the application of haircuts, the size of which reflect the liquidity, credit, interest rate and valuation risk of the asset.

In times of regular market functioning, the amount of funds that banks obtain in central bank credit operations is usually determined by market forces. In the case of the Eurosystem's main refinancing operations under variable rates and fixed allotment ${ }^{2}$, the allotted liquidity depended on the interest rate that a counterparty was willing to pay. However, when central banks provide ample liquidity - as in the Eurosystem's marginal lending facility and the Fed discount window or under temporary procedures in crisis times ${ }^{3}$ - the liquidity that counterparties can obtain is mainly limited

\footnotetext{
The SMP was discontinued after the announcement of the OMT.

This procedure was standard for main refinancing operations that settled prior to 15 October 2008.

As from the operation settled on 15 October 2008, the weekly main refinancing operations of the Eurosystem were carried out through a fixed-rate tender procedure with full allotment at the interest rate on the main refinancing operation for as long as needed.
} 
by the collateral they have available. A financial institution with limited access to funding markets or in an otherwise stressed environment may have difficulties submitting a sufficient amount of collateral to obtain the amount of liquidity it needs to run its operations. Changes in the market value of collateral assets therefore may affect banks' ability to access central bank funding in spite of ample central bank liquidity provision. Such a scenario could hamper an appropriate transmission of the central bank's policy stance to the real economy.

The literature identifies various channels of causal relationships that describe in general terms how transaction cost shocks could affect collateral value. They are schematically summarised in Figure 1. The arrows in the graph indicate how an increase in transaction costs triggers up- or downward adjustments in other market variables according to the findings in prior research.

Figure 1: Channels from an increase in transaction costs to collateral value

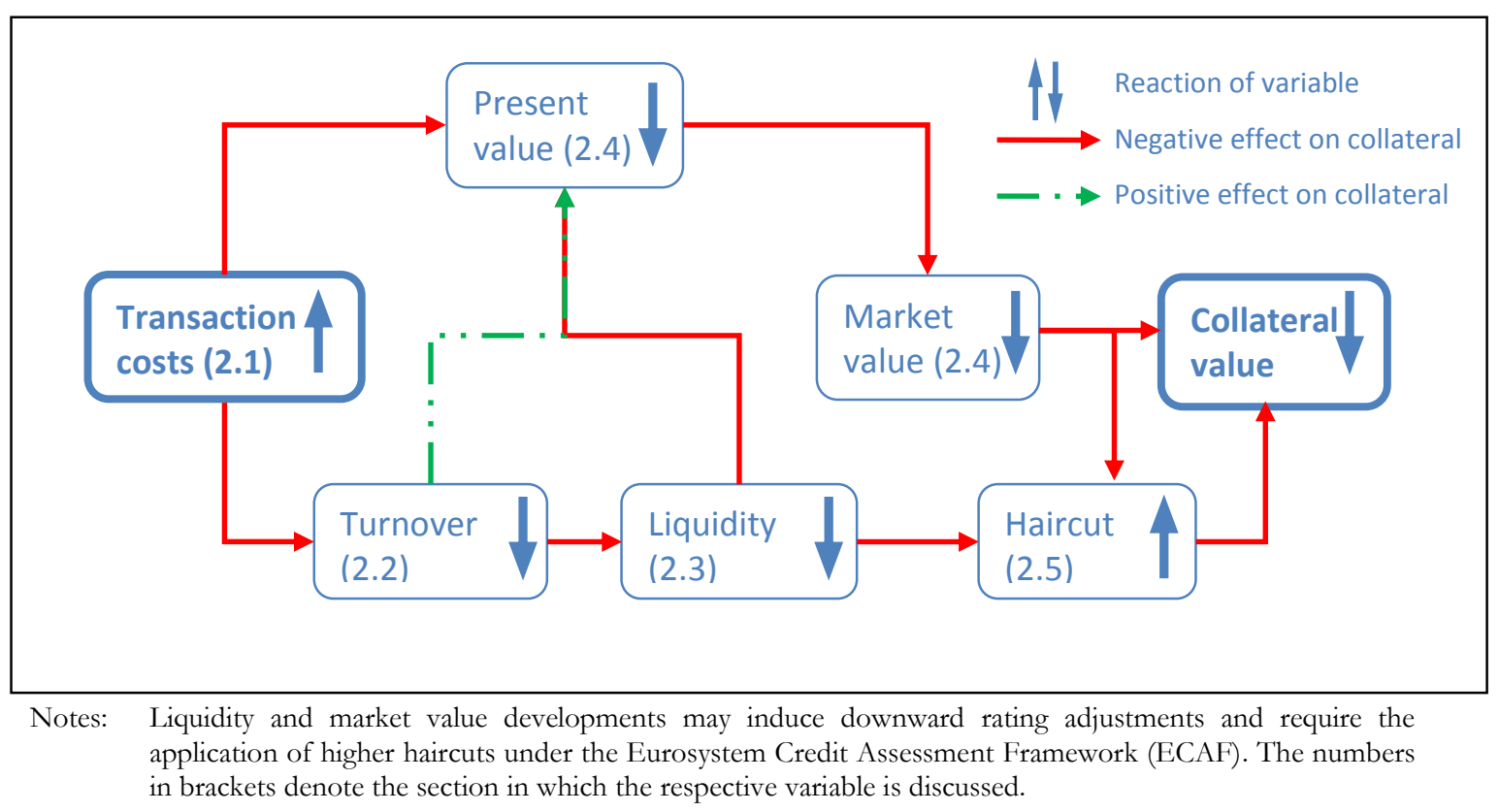

\subsection{Transaction costs in financial markets}

Transaction costs in financial markets are composed of bid-ask spreads, commission, fees, taxes, delay cost, price appreciation, market impact, timing risk and opportunity cost (Wagner \& Edwards, 1993; Kissell, 2006). A transaction cost shock hence alters the wedge between the price of the seller and the buyer and influences trading behaviour. In their summary of the transaction costs literature, Pollin et al. (2003) conclude that transaction costs vary strongly across markets and within markets, depending on market and asset characteristics as well as trading behaviour. Keim and Madhavan (1998) confirm this result, finding that the transaction costs of trading vary significantly with the size of the trade, the size of the corporation being traded and the trading infrastructure. For small firms, trading costs are high, likely driven by low trading volumes. Reiss and Werner (1996) confirm high transaction costs for small firms. A spread measure they develop is 0.71 of trading volume for large firms and 2.28 for small firms. In this context, Pollin et al. (2003) make the important observation that a uniform transaction cost shock on asset prices, e.g. a tax, 
can be highly distortive as the asset price as reference base is not comparable across assets. They show how bonds of different maturities can be affected very heterogeneously.

Several authors have observed a general trend of declining transaction costs over time. Hong and Warga (2000) demonstrate that corporate bond spreads have declined over time and that trades in U.S. government bonds have even become a zero-profit business for dealers. Driessen et al. (2005) work with a dataset of US Treasury Bills prices and show that the average bid-ask spread for 1-, 3-, 6- and 9-month maturities has fallen by roughly 75\% when comparing the 1972-1997 and 1987-1997 periods. More generally, it is argued that a transaction cost shock would be felt most (least) in market segments where transaction costs are already low (high). Constantinides (1986) also concludes that a general increase in transaction costs across markets affects more strongly those segments where the transaction costs were low initially.

Overall, the presence of transaction costs and their size and development in different market segments is well documented in the literature. Transaction cost shocks affect assets heterogeneously.

\subsection{Transaction costs and asset prices}

The market value or price of an asset is determined by the sum of its discounted future cash flows. Hence, the price of an asset declines by the present value of the transaction cost shock payable on all future transactions of this specific security (Hawkins \& McCrae, 2002). Importantly, a transaction cost shock affects all investors that value their assets at market prices, not only those that engage in trading activity. This becomes clearer when looking at the case analytically. Matheson (2011) presents a model of the impact of a transactions tax on security valuation and cost of capital for share prices. Based on this we derive a simple framework for exploring the same for fixed-income securities, drawing on a simple present value calculation. The price of a fixedincome security - a typical asset class for central bank collateral - under the presence of transaction costs can be given as

$$
\begin{aligned}
p & =\left(\sum_{t=1}^{T} \frac{c f-\Delta \tau \frac{\sum_{j=1}^{N_{t}} p_{j} q_{j}}{S_{t}^{a}}}{(1+i)^{t}}\right)+f(1+i)^{-T} \\
& =\left(c f-\Delta \tau \frac{V_{t}}{S_{t}^{a}}\right)\left(\frac{1-(1-i)^{-T}}{i}\right)+f(1+i)^{-T}
\end{aligned}
$$

where $c$ is the coupon rate, $f$ is the nominal, redemption or face value of a bond, $N_{t}$ designates the number of transactions $j$ within period $t$ (typically a year), $p_{j}$ and $q_{j}$ stand for the price and quantity of transaction $j, \Delta \tau$ is the transaction cost shock, $i$ is the yield to maturity observed in the 
market prior to the transaction cost shock and $S_{t}^{a}$ is the number of outstanding titles per security that are held for trade or available for sale and not held to maturity. ${ }^{4}$

In this equation the transaction cost shock is modelled as a negative cash flow that is deducted from the positive cash flow resulting from the coupon payment $c$. This modelling ensures an appropriate discounting of the cash flows caused by the costs on future transactions. We also assume a market populated by homogenous traders. The representative trader buys an asset with the intention to re-sell it at a later stage. Hence, the trader does not only take into account the transaction costs paid on the purchase of the asset but also factors in that the next purchaser in the future will do the same. Hence, the trader expects that the next purchaser will slightly decrease his or her offering price and thus the buyer in the present will do the same. In this way, transaction costs accumulate over the residual maturity of the asset and imply negative cash flows that lower the return of the asset. In contrast, if the marginal investor were to buy and hold the asset, then the price would not depend on the turnover and an increase in transaction costs by $\Delta \tau$ would just imply a decrease in the price by $\Delta \tau$.

The change rather than the level of the transaction cost, $\Delta \tau$, enters the model because the absolute level of transaction costs is already priced in by market participants and hence contained in the yield to maturity $i$ that is observed in the market prior to the credible announcement of the introduction of a transaction cost shock. This does not mean that the initial transaction costs are zero. Multiplying the $\Delta \tau$ with the total trading volume over all transactions observed for the security in period $t, V_{t}$, gives the tax due for the security as a whole. This figure is then scaled by the number of outstanding titles of the security that are available for trade and not held to maturity in period $t, S_{t}^{a}$. This figure is a theoretical concept and cannot be empirically observed in a reliable manner. The scaled net cash flow per period $t$ and title, i.e. the coupon minus the transaction cost, is discounted over the time to maturity. This naturally assumes that the transaction volume is the same in all future years. This assumption can be relaxed to take into account second-round effects as we will show in section 3.4.3. The overall effect on the asset price is negative. Kupiec (1996) comes to the same conclusion when analysing the effects of a transaction cost shock on asset prices in a general equilibrium model.

In addition to the direct effect of transaction costs on the asset price, the specification in equation (1) also reveals that the turnover volume $V_{t}$ influences the asset price. As turnover can be expected to decline in reaction to an upward transaction cost shock, the negative cash flow in each period would actually be reduced. Hence, a decline in turnover dampens the decline of the asset price. This second-round effect is reflected by the dotted green arrow in Figure 1.

Furthermore, the price of an asset in the market is also influenced by the liquidity of its market because investors - in particular those that do not plan to hold the asset until maturity - are interested in being able to re-sell the asset at any time without affecting the asset's price. Their willingness to hold and pay for that asset would decline in comparison to assets not affected by a transaction cost shock. This demand shock would lead to a further decline of asset prices (see Block (2007) and Acharya and Pedersen (2005)). The liquidity premium is implicitly contained in

4 This assumes that assets in held-for-trading or available-for-sale portfolios are valued at fair value while assets in held-tomaturity portfolios would be valued at amortised cost and therefore not be affected by market price changes. 
the yield in the above price that reflects the return that investors in the market demand for more or less liquidity. More liquid assets will ceteris paribus trade at a lower yield.

The downward effect of transaction cost shocks on asset prices has been documented empirically by several authors, in particular for transaction taxes. Umlauf (1993) finds that the introduction of a transaction tax on equities of one per cent in Sweden in 1984 resulted in a decline of market prices at the Stockholm stock exchange of about 5.3 per cent for the 10-day period up to and including the announcement. On the day of announcement, the index decreased 2.2 per cent. However, we note that the findings for Sweden may not be representative due to the peculiar design of the tax. Saporta and Kan (1997) analyse the price developments of UK equity shares in the surroundings of changes in the UK stamp duty, both through announcement effects on the index and by comparing price developments of American Depository Receipts and their underlying shares. They find evidence that the stamp duty is capitalised in prices. However, both Umlauf as well as Saporta and Kan cannot control for other possible influences, in particular policy announcements made on the same day. Abstracting from second-round effects on turnover and assuming a dividend yield of 4\%, Hawkins and McCrae (2002) expect a 3.1\% increase in share prices upon halving the UK stamp duty. Further evidence is presented by $\mathrm{Hu}$ (1998), Schwert und Senguin (1993), Bond et al. (2004) and Oxera (2007). Several authors find elasticities of share prices with respect to transaction costs to be around $-0.2 \%$ for the UK stamp duty.

\section{A micro model of the Eurosystem collateral framework}

The previous section has established the theoretical links between a change in transaction costs of an asset and its value as central bank collateral. In addition, empirical estimates for the market price effects of a transaction cost shock were collected from prior literature. However, these estimates can only serve as rough guidance for the degree to which a transaction cost shock may impact the value of central bank collateral. To obtain more refined estimates of that impact, this study needs to take into account more specific information on the micro level, in particular asset and counterparty heterogeneity. Asset heterogeneity means that asset values react heterogeneously to a transaction cost shock, depending on an asset's individual characteristics. For example, the price of a bond that is traded more often within a given period of time than another bond is expected, ceteris paribus, to be relatively more affected by such a shock. Counterparty heterogeneity refers to the fact that the composition of a counterparty's collateral pool depends on the counterparty's individual characteristics such as size, business model or geographical location. As a result, some counterparties are expected to be more affected by a transaction cost shock than others. In an extreme case, a counterparty that is collateral-constrained may be forced to either repay liquidity obtained from the central bank or submit additional collateral in order to remedy a situation of under-collateralisation.

Asset and counterparty heterogeneity call for a methodological approach that can take into account the micro level characteristics of assets and counterparties when determining changes in collateral value. Therefore, we have opted to develop a micro-simulation model that quantifies the effects of a transaction cost shock on collateral value on an asset-by-asset and counterparty-bycounterparty basis. The empirical setting of our analysis is the collateral framework of the 
Eurosystem, which is described in section 3.1 before we turn to the description of the dataset and the construction of the micro-simulation model in the subsequent sections.

\subsection{The Eurosystem collateral framework}

According to Article 18.1 of the Statute of the European System of Central Banks and of the European Central Bank, ${ }^{5}$ Eurosystem credit operations must be "based on adequate collateral". This way the Eurosystem ensures that it is protected against losses arising from monetary policy operations, while enabling access to central bank operations for a wide range of counterparties. To implement this operationally the Eurosystem developed a catalogue of eligibility criteria for marketable as well as non-marketable assets. ${ }^{6}$ For marketable assets, the ECB maintains a public list of eligible assets that counterparties may choose to pledge as collateral. Marketable assets are further grouped into central government securities, regional government securities, uncovered bank bonds, covered bank bonds, corporate bonds, asset-backed securities and other marketable assets. Non-marketable assets comprise credit claims, cash deposits, retail mortgage-backed debt instruments and fixed-term deposits.

Collateral that is mobilised by a counterparty towards a Eurosystem central bank is marked-tomarket prices on a daily basis. The most representative market price is maintained by the Common Eurosystem Pricing Hub. If no representative market price is available, assets are valued theoretically. Importantly, market price developments - caused, for example, by a change of transaction costs - immediately affect the lendable collateral value. In addition, the Eurosystem mitigates the risks of financial loss related to an asset by applying valuation haircuts, variation margins, concentration limits, initial margins and other measures. ${ }^{7}$ Standard valuation haircuts range from 0.5 to 65 per cent. The haircuts reflect the liquidity, credit and interest rate risk of the asset. In some cases additional valuation mark-downs are applied for collateral in foreign denominations.

Available under http://www.ecb.europa.eu/ecb/legal/pdf/en statute from c 11520080509en02010328.pdf.

The eligibility criteria for all assets are codified in Annex I to the ECB Guideline ECB/2011/14, the General Documentation, which is available under http://www.ecb.europa.eu/ecb/legal/pdf/1 33120111214en000100951.pdf.

See Box 7 of the General Documentation, ibid. 
Table 1: Use of collateral by Eurosystem counterparties

\begin{tabular}{|c|c|c|c|c|c|c|c|c|c|c|c|c|c|}
\hline \multirow{2}{*}{ Asset type } & \multirow{2}{*}{2004} & \multirow{2}{*}{2005} & \multirow{2}{*}{2006} & \multirow{2}{*}{2007} & \multirow{2}{*}{2008} & \multirow{2}{*}{2009} & \multirow{2}{*}{2010} & \multirow{2}{*}{2011} & \multicolumn{4}{|c|}{2012} & \multirow{2}{*}{$\frac{2014}{\text { Q1 }}$} \\
\hline & & & & & & & & & Q1 & Q2 & Q3 & Q4 & \\
\hline $\begin{array}{l}\text { Central government } \\
\text { securities }\end{array}$ & 252.4 & 233.5 & 205.5 & 176.9 & 158.2 & 224.9 & 261.5 & 255.0 & 336.4 & 358.2 & 368.4 & 374.3 & 320.5 \\
\hline $\begin{array}{l}\text { Regional government } \\
\text { securities }\end{array}$ & 57.7 & 64.8 & 61.3 & 53.4 & 62.2 & 70.5 & 71.0 & 82.1 & 99.8 & 98.5 & 97.7 & 100.6 & 96.5 \\
\hline $\begin{array}{l}\text { Uncovered bank } \\
\text { bonds }\end{array}$ & 169.3 & 226.5 & 294.1 & 370.6 & 439.6 & 562.1 & 430.2 & 269.2 & 369.3 & 374.2 & 341.8 & 328.8 & 260.6 \\
\hline Covered bank bonds & 213.3 & 190.1 & 172.5 & 162.8 & 173.9 & 272.8 & 264.5 & 287.8 & 404.1 & 423.1 & 488.8 & 498.8 & 377.7 \\
\hline Corporate bonds & 26.9 & 44.2 & 60.0 & 76.5 & 95.8 & 115.2 & 101.7 & 95.7 & 95.6 & 95.4 & 88.3 & 85.3 & 106.7 \\
\hline $\begin{array}{l}\text { Asset-backed } \\
\text { securities }\end{array}$ & 45.0 & 83.5 & 109.3 & 182.1 & 443.6 & 473.6 & 490.0 & 358.0 & 407.5 & 407.3 & 371.7 & 352.7 & 306.6 \\
\hline $\begin{array}{l}\text { Other marketable } \\
\text { assets }\end{array}$ & 18.9 & 22.0 & 19.9 & 16.2 & 15.8 & 21.0 & 32.7 & 57.8 & 73.8 & 77.9 & 95.1 & 81.2 & 117.5 \\
\hline $\begin{array}{l}\text { Non-marketable } \\
\text { assets }\end{array}$ & 33.5 & 35.4 & 36.3 & 109.3 & 190.1 & 294.8 & 358.5 & 418.7 & 587.6 & 621.0 & 668.4 & 656.5 & 527.3 \\
\hline Total & 817 & 900 & 959 & 1,148 & 1,579 & 2,035 & 2,010 & 1,824 & 2,374 & 2,456 & 2,520 & 2,478 & 2,113 \\
\hline
\end{tabular}

Notes: EUR billion, after valuation and haircuts, averages of end of month data over each time period shown.

Source: ECB, for a full and current time series see http://www.ecb.europa.eu/paym/pdf/collateral/collateral data.pdf

During quarter 3 of 2012 the average nominal amount of eligible marketable assets amounted to EUR 13,644 billion, among which central government securities and uncovered bank bonds were the two largest asset groups with EUR 5,998 billion and EUR 2,429 billion respectively ${ }^{8}$. However, the average outstanding credit of the Eurosystem amounted to EUR 1,216 billion while the peak outstanding credit in the same period was EUR 1,282 billion. This volume of outstanding credit was collateralised with assets of an average value after valuation and haircuts during quarter 3 of 2012 of EUR 2,520 billion. The use of collateral is summarised in Table 1. In quarter 3 of 2012, non-marketable assets were the largest collateral asset type with EUR 668 billion, followed by covered bonds, asset backed securities and central government debt instruments.

\subsection{The construction of the dataset}

In this section we explain the construction of our dataset of Eurosystem collateral. We select 12,000 assets that were registered on the Eurosystem's single list of eligible marketable assets at a point in time during quarter 3 of 2012 and randomly assign these assets to 1,800 hypothetical counterparties. In addition, each counterparty is assigned a random volume of non-marketable collateral. We obtain a many-to-many relationship, more precisely an n:m relationship, between counterparty identifiers and asset identification numbers. The resulting dataset contains 221,100 observations. For each counterparty-ISIN combination the dataset contains the hypothetical nominal amount of the asset that the counterparty has pledged as collateral. In a final step, the volume of the collateral after haircuts is scaled to the amounts observed per asset class at the end

8 Available under http://www.ecb.europa.eu/paym/pdf/collateral/collateral data.pdf. 
of the third quarter 2012. The sum of collateral value after haircuts per asset class in our dataset hence matches the figures pictured in the respective column of Table 1.

Besides the nominal amount submitted as collateral the dataset contains a series of other asset characteristics, such as asset type, price, coupon frequency, coupon structure, residual maturity, issuance date, maturity date, redemption value, liquidity category (as defined by the Eurosystem) and the Eurosystem valuation haircut. The majority of variables are obtained from the list of eligible marketable assets published by the ECB. Prices are obtained from the Common Eurosystem Pricing Hub. ${ }^{9}$ We use asset characteristics to compute the yield to maturity. The resulting value is verified against the yield to maturity reported by Bloomberg. All variables and their sources are explained in detail in Annex 1.

The dataset is further enriched with information on asset turnover. The data covers 1,161,629 transactions in the secondary market of 50 European exchanges or trading platforms between 1 December 2012 and 1 March 2013. Altogether, we observe zero or a positive number of transactions for 9,031 of the 12,000 securities in our sample. For the remaining 2,969 securities trading information is missing and could either be zero or positive.

\subsection{Descriptive statistics}

In the following we present some descriptive statistics of our simulated dataset on asset and counterparty level. Table 2 summarises the characteristics of the marketable assets in our dataset. We disregard the non-marketable assets in the table because they display very different characteristics. The residual maturity of marketable assets ranges from two days to almost 100 years, with the mean at around six years and the median at close to three years. The predominant coupon frequency is one annual payment but other also patterns occur. The average coupon rate is at 2.6 per cent, ranging from zero-coupon bonds to a maximum of 16.7 per cent. Asset prices average at EUR 98.03. Although the minimum and maximum are far from the standard par value of EUR 100, the standard deviation is at only EUR 12.61, which confirms that the majority of assets trade within a reasonable corridor around par. The predominant redemption value in the dataset is EUR 100. The yield ranges from 0 to 22 per cent, with the mean and median both around 1.9 per cent. The yield figures reasonably reflect the maturity profile of the assets in the dataset as well as the interest rate level prevailing at the time of observation. Overall, the table confirms that outliers can be justified and do not distort the aggregate characteristics of the dataset. Haircuts range from 0.5 to 68 per cent in line with the Eurosystem haircut schedule valid at the time.

9 The CEPH collects market prices from various sources and defines the most reliable one on a given business day. See also http://www.ecb.europa.eu/mopo/assets/risk/valuation/html/index.en.html. 
Table 2: Descriptive statistics for marketable assets

\begin{tabular}{lrrrrrrr}
\hline \hline Variable & Mean & Min & $\begin{array}{c}\mathbf{1 0}^{\text {th }} \\
\text { percentile }\end{array}$ & Median & $\begin{array}{c}\mathbf{9 0}^{\text {th }} \\
\text { percentile }\end{array}$ & Max & $\begin{array}{c}\text { Standard } \\
\text { deviation }\end{array}$ \\
\hline Residual maturity [days] & 2,172 & 2 & 166 & 1,034 & 4,301 & 35,929 & 3,803 \\
Coupon frequency & 1.83 & - & 1.00 & 1.00 & 4.00 & 4.00 & 1.32 \\
Coupon rate [\%] & 2.6 & 0.0 & 0.4 & 2.5 & 4.9 & 16.7 & 1.8 \\
Price [EUR] & 98.03 & 13.59 & 88.43 & 99.80 & 108.63 & 499.93 & 12.61 \\
Redemption value [EUR] & 100.58 & 35.00 & 100.00 & 100.00 & 100.00 & $1,000.00$ & 15.21 \\
Yield [\%] & 1.912 & 0.000 & 0.523 & 1.879 & 3.298 & 22.199 & 1.138 \\
Haircut [\%] & 8.0 & 0.5 & 1.5 & 6.5 & 16.0 & 68.0 & 7.0 \\
\hline \hline
\end{tabular}

Table 3 shows the value of submitted collateral by asset type in the simulated dataset. The figures in the first column are identical with the column for quarter 3 of 2012 in Table 1 as the collateral values in the simulated dataset are scaled to that point in time. The second column displays the share of the respective asset type of the total collateral value.

Table 3: Simulated collateral value by asset type

\begin{tabular}{lcr}
\hline \hline Asset type & $\begin{array}{c}\text { Collateral value } \\
\text { [EUR million] }\end{array}$ & $\begin{array}{c}\text { Share } \\
{[\%]}\end{array}$ \\
\hline Central government securities & 368,400 & 14.6 \\
Regional government securities & 97,700 & 3.9 \\
Uncovered bank bonds & 341,800 & 13.6 \\
Covered bank bonds & 488,800 & 19.4 \\
Corporate bonds & 88,300 & 3.5 \\
Asset-backed securities & 371,700 & 14.7 \\
Other marketable assets & 95,100 & 3.8 \\
Non-marketable assets & 668,400 & 26.5 \\
\hline Total & $\mathbf{2 , 5 2 0 , 2 0 0}$ & $\mathbf{1 0 0 . 0}$ \\
\hline \hline Notes: Collateral values after valuation and haircuts, averages of end of
\end{tabular}

Table 4 shows the counterparty characteristics in our simulated dataset. The number of different securities submitted by counterparties ranges from one at the lower end to over 2,000 at the upper end. On average, counterparties post 212 different securities in their collateral pool. The value of 
counterparties' collateral pools ranges from close to EUR 600,000 at the $1^{\text {st }}$ percentile to roughly EUR 34 billion at the $99^{\text {th }}$ percentile. The collateral pool at the median is worth EUR 58 million for lending. The value of central government securities as a per cent of the total value of the collateral pool ranges from 0 to 100 per cent, with 13 per cent at the mean. All numbers refer to the simulated dataset described above. Overall, the table reflects the typical skewedness of firmlevel data where many small and a few large entities cause the mean and median to differ significantly from each other.

Table 4: Descriptive statistics for counterparties

\begin{tabular}{|c|c|c|c|c|c|c|c|}
\hline Variable & Mean & $\begin{array}{c}1^{\text {st }} \\
\text { percentile }\end{array}$ & $\begin{array}{c}10^{\text {th }} \\
\text { percentile }\end{array}$ & Median & $\begin{array}{c}90^{\text {th }} \\
\text { percentile }\end{array}$ & $\begin{array}{c}\text { 99th } \\
\text { percentile }\end{array}$ & $\begin{array}{l}\text { Standard } \\
\text { deviation }\end{array}$ \\
\hline $\begin{array}{l}\text { Number of different } \\
\text { submitted securities }\end{array}$ & 212 & 1 & 2 & 10 & 80 & 2,168 & 897 \\
\hline $\begin{array}{l}\text { Value of collateral } \\
\text { pool } \\
\text { [EUR million] }\end{array}$ & 1,398.6 & 0.6 & 5.1 & 57.8 & $1,929.5$ & $34,212.4$ & $5,993.5$ \\
\hline $\begin{array}{l}\text { Value of central } \\
\text { government securities } \\
\text { against total pool }[\%]\end{array}$ & 12.8 & 0.0 & 0.0 & 0.0 & 57.7 & 100.0 & 27.6 \\
\hline
\end{tabular}

\subsection{The structure of the micro model}

In this section we develop the micro model that is used to simulate the effects of a transaction cost shock on central bank collateral. The model builds on the theory developed in section 2 . The simulations are carried out in various scenarios with different parameters as pictured in Table 5. Scenarios I-III all foresee a positive transaction cost shock. The transaction cost shock could of course also be negative but we stick to positive shocks for simplicity only. Scenarios II and III introduce, in addition, second-round effects in the turnover of securities. A change in transaction costs has a considerable effect on trading turnover. These additional scenarios take into account this important effect. We call this a second-round effect because it is not necessarily intended by a policy action and results from changes in market participants' behaviour in response to the altered transaction cost. Beyond the second-round effects on turnover, the model does not take into account any other dynamics over time, nor does it deal with indirect effects running through liquidity or haircuts. Hence, any changes in liquidity premia or credit risk ratings caused by a transaction cost shock remain outside the model we develop here. 
Table 5: Overview of scenario parameters

\begin{tabular}{lrr}
\hline \hline & $\begin{array}{c}\text { Transaction } \\
\text { cost shock } \\
(\Delta \tau)\end{array}$ & $\begin{array}{c}\text { Second-round } \\
\text { effect on turnover } \\
\left(\frac{\Delta V_{t}}{V_{t}}\right)\end{array}$ \\
\hline Base scenario & 0 & - \\
Scenario I & $0.1 \%$ & 0 \\
Scenario II & $0.1 \%$ & $-25 \%$ \\
Scenario III & $0.1 \%$ & $-75 \%$ \\
\hline \hline
\end{tabular}

\subsubsection{Base scenario}

In the base scenario, the asset characteristics observed in the dataset are used to compute the base line price of each security based on a standard price function for fixed-income securities

$$
p=\left(\sum_{t=1}^{T} \frac{c f}{(1+i)^{t}}\right)+f(1+i)^{-T}
$$

where $c$ is the coupon rate, $f$ is the nominal or face value, $T$ stands for the years until maturity and $i$ is the yield to maturity. The price obtained in this computation is validated against the price observed in the dataset to ensure that the simulation functions appropriately.

In a further step, the model applies haircuts on the simulated market price of the collateral assets in line with risk control measures of the Eurosystem. The haircut is determined by the credit quality, the residual maturity, the coupon structure and the liquidity category on an asset-by-asset basis. Additional haircuts are applicable for certain foreign currency denominations, theoretical pricing and some asset groups (e.g. asset-backed securities). The collateral value after haircuts is the lendable value of the assets that determines the volume of liquidity that counterparties can be allotted in a central bank operation.

\subsubsection{Simulation of first-round effect}

The simulation of first-round effects in scenario I extends equation (2) by inserting a transaction cost shock. 


$$
\begin{aligned}
p & =\left(\sum_{t=1}^{T} \frac{c f-\Delta \tau \frac{V^{o}}{S_{o}}}{(1+i)^{t}}\right)+f(1+i)^{-T} \\
& =\left(\sum_{t=1}^{T} \frac{\left(c-\Delta \tau \frac{V^{o}}{S_{o} f}\right) f}{(1+i)^{t}}\right)+f(1+i)^{-T} \\
& =\left(\sum_{t=1}^{T} \frac{\left(c-\Delta \tau v^{o}\right) f}{(1+i)^{t}}\right)+f(1+i)^{-T}
\end{aligned}
$$

In fact, this formula is based on equation (1) that was derived and explained in the theoretical section. To recall, the coupon rate $c$ multiplied by the face value $f$ yields the positive annual cash flow of the bond. From this we deduct the negative cash flow caused by the transaction cost. For the scenarios we assume a transaction cost shock $\Delta \tau$ of $+0.1 \%$. We note that one important characteristic of our model is that we assume that initial transaction costs are zero while in practice, many of the assets in our sample have large transaction costs, that already drive prices down, which would imply that the impact of any additional shock would be lower than our estimates suggest.

The shock size is realistic compared with the transaction costs that prevail across the wide range of different markets in which collateral assets are traded. For sovereign bond markets with tight spreads of around $0.05 \%$ the shock is relatively large. However, other debt instruments trade with much higher spreads of above $0.1 \%$. Another approach would be to compare the assumed shock to securities transaction tax rates. The regular UK Stamp Duty Reserve Tax is charged at a rate of $0.5 \%$. The transaction tax proposed by the European Commission in 2011 has a standard rate of $0.1 \%$. The transaction cost shock is multiplied with a measure of annual secondary market turnover, $V^{o}$. The resulting aggregate negative cash flow caused by the transaction cost shock is obtained on the security level. It is therefore scaled by the number of outstanding titles per security, $S_{o}$. For further illustration, Annex 2 applies the first line of equation (3) to three exemplary bonds with different maturities and coupon rates. For the model, we transform the equation in two steps. The cash flow then reads $\left(c-\Delta \tau v^{o}\right)$ where $v^{o}$ is the turnover ratio of a certain security (the whole issue or ISIN).

In the model, the formula is applied to all 12,000 marketable assets that are used as central bank collateral by the 1,800 counterparties in the simulated dataset. For non-marketable assets it is assumed for simplicity under all scenarios that a transaction cost shock does not cause any change in their value. ${ }^{10}$ The application of haircuts is identical to the base scenario in all alternative scenarios as we assume haircut sizes not to be affected by the transaction cost shock in our model.

\subsubsection{Simulation of second-round turnover effects}

For the simulation of second-round effects of a transaction cost shock on turnover, equation (3) is further enhanced with a change in turnover.

10 It could be argued that the demand for non-marketable assets rises (falls) with the increase (decrease) of transaction costs. 


$$
p=\left(\sum_{t=1}^{T} \frac{\left(c-\varphi \Delta \tau v^{o}\right) f}{(1+i)^{t}}\right)+f(1+i)^{-T}
$$

where

$$
\varphi=1+\frac{\Delta v^{o}}{v^{o}}=1+\frac{\Delta V^{o}}{V^{o}}
$$

The second-round effect $\varphi$ depends on the percentage change in turnover $\frac{\Delta V^{o}}{V^{o}}$. The equation is again applied to the three exemplary bonds in Annex 2 for further illustration. In scenario II a turnover decrease of $25 \%$ is assumed in the case of a positive transaction cost shock. In scenario III the decrease is assumed to be $75 \%$. The assumptions for second-round effects in the model are fully hypothetical and apply to all assets in the same way. In reality, second-round effects are likely to differ across maturity, asset types, market liquidity, etc. In addition, second-round effects are likely to lead to further changes in other variables. Specifically, we analyse how an increase in transaction costs decreases volume, so that transaction costs are paid less often, thus attenuating the negative impact of transaction costs on the asset value. However, it could be expected that an increase in transaction costs (negatively affecting the asset price), decreases the trading volume (positively affecting the asset price), which in turn complicates dealers' ability to find counterparties, thus reducing liquidity (again, negatively affecting the asset price). In our analysis we assume that the positive 'volume' effect dominates the resulting negative 'liquidity' effect though we acknowledge that we do not have any information on the magnitude of either of these effects. Annex 3 illustrates what the scenarios we assume here imply in terms of elasticities of turnover with respect to transaction costs. A comparison of the implied elasticities with those observed by the literature we have cited in section 2.2 shows that they lie within the range observed empirically.

\subsubsection{Computing the turnover ratio}

This section explains how we use the information on trading volume in the dataset to compute the turnover ratio that is used in line with equation (4). The data on trading volume suffers from two shortcomings, which are typical of trading data. First, for some assets no trading data is available at all. Second, the data only covers a segment of the overall market turnover because over-the-counter (OTC) transactions are likely to be underrepresented. In order to deal with these shortcomings we adopt a dual approach. On the one hand, we propose a workaround for the shortcomings that allows us to still use the trading data as a source of variance. On the other hand, we conduct a robustness check which fully abstracts from the trading data at the asset level. In the following we explain both approaches - baseline and robustness check - one by one.

For the baseline approach, we aggregate the transaction-level information in the dataset over time by asset and obtain quarterly transaction volumes. For the assets in our sample for which no transaction information is available we impute transaction volumes. We opt for a cell-mean imputation using the geographical residence of the issuer and the asset type as the two categorical variables defining the cells. This method has the disadvantage that the variance of the underlying population is underestimated by the sample variance after imputation, even when assuming that 
the observations are missing at random. However, cell-mean imputation still serves the purpose of the study because we do not aim at making inferences in a multivariate analysis where coefficients would be biased. The main objective of our imputation is to avoid selection bias in transaction volumes.

The underrepresentation of OTC transactions implies that even for the securities for which we do observe transactions our figures very likely understate the true size of the secondary market. This is a common challenge of transactions data that cannot be easily overcome because OTC transaction data are not centrally collected. As a workaround we obtained turnover data for the three biggest secondary debt markets in the euro area. Based on this information we scale up the turnover volume for all assets in the dataset. Finally we scale by the average nominal value outstanding to obtain the turnover ratio $v^{o}$ used in equations (3) and (4). We explain our method in more detail in Annex 4. The disadvantage of this workaround is that the missing observations are likely not missing at random. Rather, the availability of data may be thinner for some specific asset types, trading venues or countries. Extrapolating our information on turnover in sovereign debt markets into other asset categories may be imprecise but given the unavailability of better data it is a second-best solution. As we scale up turnover conservatively, the transaction data we obtain for the micro-simulation should be interpreted as a lower-bound figure when drawing empirical conclusions about the effects of transaction cost shocks.

In order to enhance the credibility of these assumptions regarding the scaling factor coupled with the underlying trading data, we carry out a robustness check. The robustness check does not rely on any trading data at the micro level. It rather assumes a turnover ratio $v^{o}$ of 5 for all assets. For comparison, the turnover ratio for German government securities in 2012 amounted to 4.7. ${ }^{11}$ The results of the robustness check are summarised in section 4.3.

Table 6: Descriptive statistics for asset turnover ratio $\left(v^{o}\right)$

\begin{tabular}{|c|c|c|c|c|c|c|c|}
\hline Variable & Mean & $\begin{array}{c}1^{\text {st }} \\
\text { percent } \\
\text { ile }\end{array}$ & $\begin{array}{c}10^{\text {th }} \\
\text { percentile }\end{array}$ & Median & $\begin{array}{c}9^{\text {th }} \\
\text { percentile }\end{array}$ & $\begin{array}{c}99^{\text {th }} \\
\text { percentile }\end{array}$ & $\begin{array}{l}\text { Standard } \\
\text { deviation }\end{array}$ \\
\hline Baseline & 28.08 & 0.00 & 0.00 & 0.00 & 11.15 & 735.38 & 297.90 \\
\hline Robustness check & 5 & 5 & 5 & 5 & 5 & 5 & 0 \\
\hline
\end{tabular}

\section{Results}

The simulation results from the three scenarios discussed above are presented in two sets. First, we show results on an asset level that reflect how the impact of a transaction cost shock on collateral value varies by different asset characteristics. Second, we move on to the counterparty level and demonstrate how different types of counterparties are affected in our simulation.

11 See Deutsche Finanzagentur (2013), Bund Fact Sheet. 
Towards the end of the section we point out some caveats regarding the results of the study and their interpretation.

\subsection{Assets}

Table 7: Simulation results by asset type

\begin{tabular}{|c|c|c|c|c|c|}
\hline Asset type & $\begin{array}{l}\Delta \tau \\
\Delta \boldsymbol{V}^{\mathbf{0}}\end{array}$ & $\begin{array}{c}\text { Base } \\
0 \% \\
0 \%\end{array}$ & $\begin{array}{c}\text { S I } \\
0.1 \% \\
0 \%\end{array}$ & $\begin{array}{c}\text { S II } \\
0.1 \% \\
-25 \%\end{array}$ & $\begin{array}{l}\text { S III } \\
0.1 \% \\
-75 \%\end{array}$ \\
\hline \multirow{2}{*}{\multicolumn{2}{|c|}{ Central government securities }} & 368,400 & 365,055 & 365,891 & 367,564 \\
\hline & & & $-0.91 \%$ & $-0.68 \%$ & $-0.23 \%$ \\
\hline \multirow{2}{*}{\multicolumn{2}{|c|}{ Regional government securities }} & 97,700 & 97,654 & 97,666 & 97,689 \\
\hline & & & $-0.05 \%$ & $-0.04 \%$ & $-0.01 \%$ \\
\hline \multirow{2}{*}{\multicolumn{2}{|c|}{ Uncovered bank bonds }} & 341,800 & 338,512 & 339,334 & 340,978 \\
\hline & & & $-0.96 \%$ & $-0.72 \%$ & $-0.24 \%$ \\
\hline \multirow{2}{*}{\multicolumn{2}{|c|}{ Covered bank bonds }} & 488,800 & 488,434 & 488,525 & 488,708 \\
\hline & & & $-0.07 \%$ & $-0.06 \%$ & $-0.02 \%$ \\
\hline \multirow{2}{*}{\multicolumn{2}{|c|}{ Corporate bonds }} & 88,300 & 88,002 & 88,076 & 88,225 \\
\hline & & & $-0.34 \%$ & $-0.25 \%$ & $-0.08 \%$ \\
\hline \multirow{2}{*}{\multicolumn{2}{|c|}{ Asset-backed securities }} & 371,700 & 371,700 & 371,700 & 371,700 \\
\hline & & & $0.00 \%$ & $0.00 \%$ & $0.00 \%$ \\
\hline \multirow{2}{*}{\multicolumn{2}{|c|}{ Other marketable assets }} & 95,100 & 94,935 & 94,976 & 95,059 \\
\hline & & & $-0.17 \%$ & $-0.13 \%$ & $-0.04 \%$ \\
\hline \multirow{2}{*}{\multicolumn{2}{|c|}{ Non-marketable assets }} & 668,400 & 668,400 & 668,400 & 668,400 \\
\hline & & & $0.00 \%$ & $0.00 \%$ & $0.00 \%$ \\
\hline \multirow{2}{*}{ Total } & & $2,520,200$ & $2,512,692$ & $2,514,569$ & $2,518,323$ \\
\hline & & & $-0.30 \%$ & $-0.22 \%$ & $-0.07 \%$ \\
\hline
\end{tabular}

In section 2 this study demonstrated theoretically why a transaction cost shock is expected to affect the value of an asset heterogeneously depending on the asset's micro characteristics. This section corroborates that finding empirically and shows simulation results for a number of selected asset characteristics across the three scenarios introduced previously. The first asset characteristic we look at is the asset type. Table 7 summarises the results in absolute levels of collateral value as well as percentage changes. The amounts in the column of the base scenario are naturally equal to the values presented in Table 1. Turning to the scenarios, scenario I presents the strongest change in collateral value $(-0.30 \%)$ of the three scenarios simulating an upward transaction cost shock. This is entirely intuitive as scenario I disregards any second-round effects of a transaction cost shock 
on turnover. The effect is considerably weaker for scenarios II and III with $-0.22 \%$ and $-0.07 \%$ respectively, for which second-round effects are taken into account.

In order to put the size of these estimates into perspective we compare them with existing literature. As the results vary considerably across studies in terms of ex-ante transaction cost level, transaction cost shock size and resulting price change, elasticity is the most useful measure to compare the various estimates. As summarised in section 2.2, several authors find that elasticities of share prices with respect to transaction costs lie at around $-0.2 \%$ for the UK stamp duty.

Table 8: Implied elasticities at a transaction cost shock of $0.1 \%$

\begin{tabular}{lccc}
\hline \hline & \multicolumn{2}{c}{ Initial transaction cost level } \\
Change of collateral value & $\mathbf{0 . 0 5 \%}$ & $\mathbf{0 . 5 0 \%}$ & $\mathbf{2 . 0 0 \%}$ \\
\hline Scenario II $(-25 \%):-0.22 \%$ & -0.001 & -0.011 & -0.044 \\
Scenario III $(-75 \%):-0.07 \%$ & -0.0004 & -0.004 & -0.014 \\
\hline \hline & Notes: $\quad \begin{array}{l}\text { For comparison, the average of the bid-ask spread within the approximately } 60 \\
\text { outstanding German Bunds is at } 0.048 \text { at the lower end. At the higher end, bid-ask spreads } \\
\text { are as high as } 2 \text { for less liquid markets. }\end{array}$
\end{tabular}

We compute the implied elasticities for scenarios II and III at three different initial transaction cost levels in Table 8 . At the transaction cost level of $0.5 \%$, we obtain elasticities ranging from 0.011 for scenario II to -0.004 for scenario III. This means that a transaction cost increase of $0.1 \%$ results in a price decline of between 20 and 5 times lower than the estimates for the UK stamp duty. The apparently large difference between the UK results can be explained as follows: First, equities are very different assets from those in our dataset and their markets behave inherently differently. Price-elasticity in equity markets could generally be higher than in the fixed-income markets that dominate our study. Second, the empirical estimates that some of the other studies are based on do not control for other possible influences on the price change and therefore likely suffer from an upward bias as Hawkins and McCrae (2002) also point out. Third, the estimates were obtained in the context of the UK stamp duty which is a very small market with many substitutes in other countries and other financial instruments. Traditionally, markets with close substitutes have a much higher elasticity. Taking these three reasons into account, the elasticities we obtain seem realistic from an empirical point of view. Our results are further supported by the percentage price changes that we obtain in our stylised mini-model in Annex 2.

The size of the effects in our study varies considerably across different asset types. As explained previously, we assume that the value of non-marketable collateral is not affected by transaction cost shocks. Uncovered bank bonds, central government assets and corporate bonds experience relatively large changes in their collateral values. We note that ABSs are not affected in our model given that our dataset does not capture any turnover for this asset class, thus completely negating the adverse impact of a transaction cost shock as simulated by our model. 
Table 9: Simulation results by residual maturity

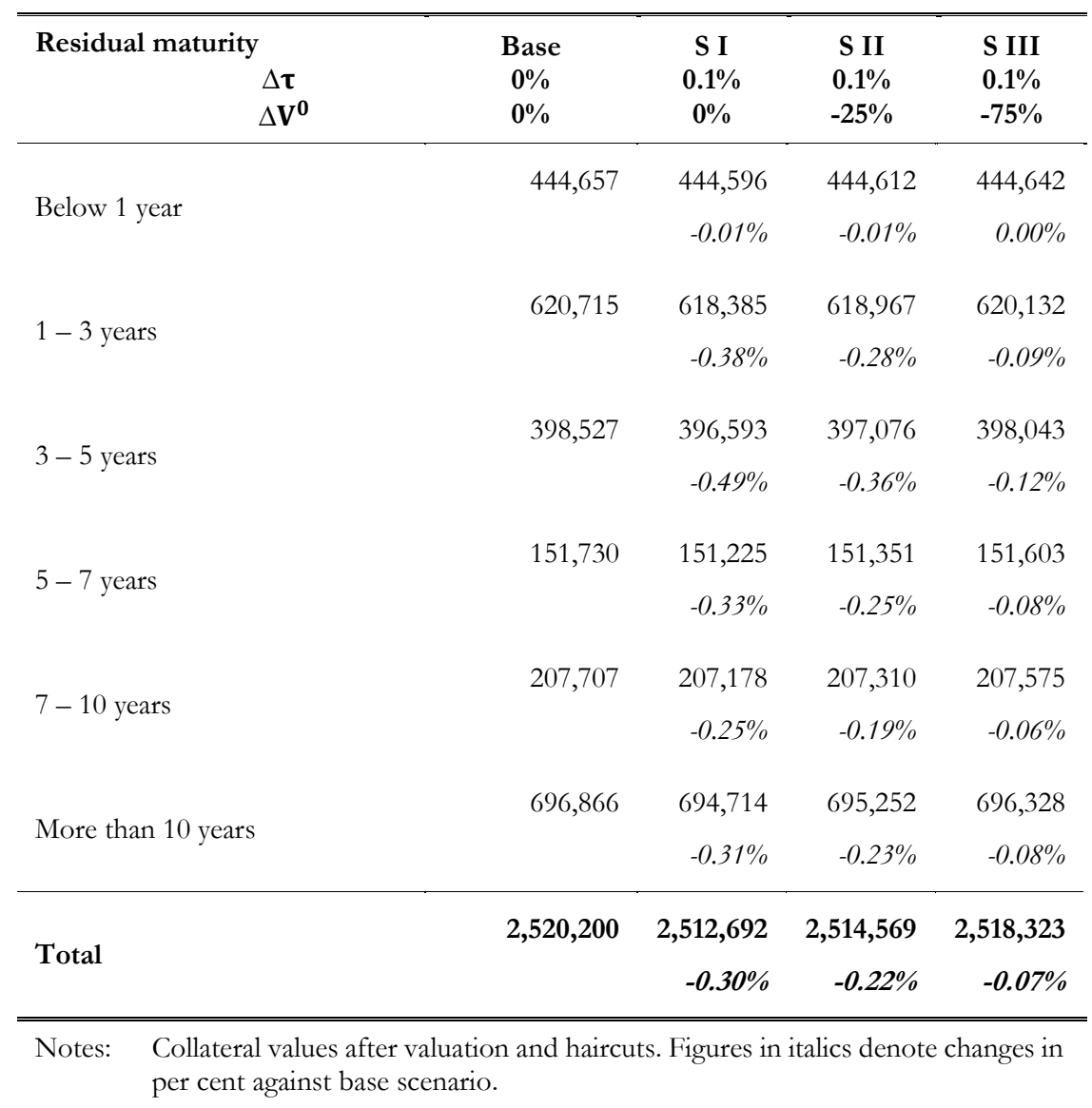

As second group of results, we look at the effect of a transaction cost shock differentiated by residual maturity. Table 9 pictures the results broken down into the six maturity buckets of the Eurosystem. Naturally, we recognise the same pattern across scenarios, with the absolute size of the effect decreasing from scenario I to III. The largest effects can be found in the maturity buckets from 3-to-5 years and 1-to-3 years. A closer inspection of the simulation on the micro level suggests that these results are driven by the asset types and transaction volumes that dominate the maturity buckets. Furthermore, we also recognise increasing effects from the first to the third maturity bucket. This reflects a pattern that is also visible in the exemplary bond simulations in Annex 2 that shows that bonds with a longer residual maturity show stronger percentage price changes. The reason for this finding is that the bond values of shorter residual maturities are dominated by the principal repayment amount, which is not affected by a transaction cost shock. Coupon payments and costs for transactions play a relatively minor role. For longer maturities, however, the value of the principal repayment is discounted more strongly. Hence, annual payments such as coupons and transaction costs affect the asset's pricing more strongly.

We furthermore disaggregate the simulation results by five haircut categories. The results are pictured in Table 10. The distribution across haircut categories is driven by the random simulation of the dataset. A transaction cost shock entails the highest effects on collateral value for assets in the $5 \%-15 \%$ haircut category, followed by the $2.5 \%-5 \%$ category. For assets with haircuts between $15 \%$ and $50 \%$ the effects are minimal because these haircut categories are dominated by 
marketable assets with lower market liquidity or non-marketable assets, for which we assume a zero effect in this study.

Table 10: Simulation results by haircuts

\begin{tabular}{|c|c|c|c|c|c|}
\hline Haircut & $\begin{array}{c}\Delta \boldsymbol{\tau} \\
\Delta \boldsymbol{V}^{\mathbf{0}}\end{array}$ & $\begin{array}{c}\text { Base } \\
0 \% \\
0 \%\end{array}$ & $\begin{array}{c}\text { S I } \\
0.1 \% \\
0 \%\end{array}$ & $\begin{array}{c}\text { S II } \\
0.1 \% \\
-25 \%\end{array}$ & $\begin{array}{l}\text { S III } \\
0.1 \% \\
-75 \%\end{array}$ \\
\hline \multirow{2}{*}{\multicolumn{2}{|c|}{ Below 2.5\% }} & 840,234 & 838,950 & 839,271 & 839,913 \\
\hline & & & $-0.15 \%$ & $-0.11 \%$ & $-0.04 \%$ \\
\hline \multirow{2}{*}{\multicolumn{2}{|c|}{$2.5 \%-5 \%$}} & 232,816 & 232,253 & 232,393 & 232,675 \\
\hline & & & $-0.24 \%$ & $-0.18 \%$ & $-0.06 \%$ \\
\hline \multirow{2}{*}{\multicolumn{2}{|c|}{$5 \%-15 \%$}} & 712,799 & 707,317 & 708,688 & 711,429 \\
\hline & & & $-0.77 \%$ & $-0.58 \%$ & $-0.19 \%$ \\
\hline \multirow{2}{*}{\multicolumn{2}{|c|}{$15 \%-50 \%$}} & 34,354 & 34,354 & 34,354 & 34,354 \\
\hline & & & $0.00 \%$ & $0.00 \%$ & $0.00 \%$ \\
\hline \multirow{2}{*}{\multicolumn{2}{|c|}{ Above $50 \%$}} & 699,997 & 699,818 & 699,863 & 699,952 \\
\hline & & & $-0.03 \%$ & $-0.02 \%$ & $-0.01 \%$ \\
\hline \multirow{2}{*}{ Total } & & $2,520,200$ & $2,512,692$ & $2,514,569$ & $2,518,323$ \\
\hline & & & $-0.30 \%$ & $-0.22 \%$ & $-0.07 \%$ \\
\hline
\end{tabular}

Finally, we disaggregate the results by credit quality step as defined by the Eurosystem. The credit quality steps reflect the credit quality as assessed by accepted external credit rating agencies. The results show that assets with a higher credit quality suffer a greater collateral value contraction following a transaction cost shock. 
Table 11: Simulation results by credit quality

\begin{tabular}{|c|c|c|c|c|c|}
\hline Credit & $\begin{array}{l}\Delta \tau \\
\Delta V^{0}\end{array}$ & $\begin{array}{c}\text { Base } \\
0 \% \\
0 \%\end{array}$ & $\begin{array}{c}\text { S I } \\
0.1 \% \\
0 \%\end{array}$ & $\begin{array}{c}\text { S II } \\
0.1 \% \\
-25 \%\end{array}$ & $\begin{array}{l}\text { S III } \\
0.1 \% \\
-75 \%\end{array}$ \\
\hline \multirow{2}{*}{\multicolumn{2}{|c|}{ Credit quality step 1 and 2}} & $1,686,857$ & $1,679,824$ & $1,681,582$ & $1,685,099$ \\
\hline & & & $-0.42 \%$ & $-0.31 \%$ & $-0.10 \%$ \\
\hline \multirow{2}{*}{\multicolumn{2}{|c|}{ Credit quality step 3}} & 164,943 & 164,468 & 164,587 & 164,824 \\
\hline & & & $-0.29 \%$ & $-0.22 \%$ & $-0.07 \%$ \\
\hline \multirow{2}{*}{\multicolumn{2}{|c|}{ Non-marketable assets }} & 668,400 & 668,400 & 668,400 & 668,400 \\
\hline & & & $0.00 \%$ & $0.00 \%$ & $0.00 \%$ \\
\hline \multirow{2}{*}{ Total } & & $2,520,200$ & $2,512,692$ & $2,514,569$ & $2,518,323$ \\
\hline & & & $-0.30 \%$ & $-0.22 \%$ & $-0.07 \%$ \\
\hline Notes: & $\begin{array}{l}\text { Collateral values } \\
\text { per cent against } \\
\text { "A" range of rat } \\
\text { range. Non-marl }\end{array}$ & $\begin{array}{l}\text { and hairc } \\
\text { The credit } \\
\text { agencies, } \\
\text { are picture }\end{array}$ & $\begin{array}{l}\text { Figures i } \\
\text { ality steps } \\
\text { dit quality } \\
\text { eparately. }\end{array}$ & $\begin{array}{l}\text { italics deno } \\
\text { and } 2 \text { corr } \\
\text { tep three } t\end{array}$ & $\begin{array}{l}\text { changes in } \\
\text { ond to the } \\
\text { he "BBB" }\end{array}$ \\
\hline
\end{tabular}

Overall, the effects across different scenarios and asset characteristics can be explained intuitively. As expected, the effects seem to be mainly driven by the turnover in the respective market segment and by the assumed second-round effects of a transaction cost shock on turnover. Compared with the exemplary calculations presented in Annex 2 the results are realistic and within the expected range.

The size of the effects can be put into perspective in a variety of ways. Given the large amount of collateral used, roughly EUR 2.5 trillion in the base scenario, the percentage changes stand for amounts in the order of billions of euros. This magnitude simply underlines the strong effect of transaction costs on the price of financial assets in general. Another way to look at the effects of the study is to translate them into changes in the implied yield. For this the new market value before haircuts resulting in the simulation is used to calculate back the implied yield. Of course, this is an entirely theoretical exercise as the implied yields would never be observed in markets due to second-round price and substitution effects brought about by arbitrage. In Annex 2 we show that the effect of a transaction cost shock on the profitability of a certain instrument in terms of its implied yield can be huge in spite of relatively small percentage changes in prices. For example, assuming a positive transaction cost shock of $0.1 \%$ for bond B with one-year residual maturity results in the yield to maturity increasing from $0.5 \%$ observed in the base scenario to an implied yield of $1.0 \%$ in scenario I and still $0.62 \%$ in scenario III after taking into account second-round effects on turnover. This effect is very large and clearly underlines that relatively small transaction cost changes can cause strong effects on market activity.

\subsection{Counterparties}

Yet another way to interpret the effects observed in the previous section is to analyse their implications for Eurosystem counterparties. For this we have aggregated the collateral on counterparty level and ranked the counterparties according to the size of their collateral pool in 
the base scenario. Collateral pool size is a - naturally imperfect - proxy of counterparty size. Table 12 shows the simulation results by counterparties in quintiles. The first quintile contains the counterparties with the smallest collateral pools and therefore stands for roughly EUR 1.7 billion of collateral only. At the other end of the distribution, the fifth quintile contains the largest collateral pools corresponding to an aggregate value of roughly EUR 2.4 trillion. In spite of the strongly skewed distribution of the collateral pool size, the effects of a transaction cost shock on collateral value is relatively balanced across pool size classes. This could, for example, be explained by the fact that the collateral pools across the five quintiles are well diversified in terms of asset classes. While this should not be misinterpreted as a proof of diversification on the micro level, it is a clear sign that small collateral pools are on average not more or less affected by a transaction cost shock than larger ones. This is overall good news for the hypothetical banking system in our dataset.

Table 12: Simulation results by counterparty quintiles

\begin{tabular}{|c|c|c|c|c|c|}
\hline Collatera & $\begin{array}{l}\text { al quintile } \\
\qquad \Delta \tau \\
\Delta V^{0}\end{array}$ & $\begin{array}{c}\text { Base } \\
0 \% \\
0 \%\end{array}$ & $\begin{array}{c}\text { S I } \\
0.1 \% \\
0 \%\end{array}$ & $\begin{array}{c}\text { S II } \\
0.1 \% \\
-25 \%\end{array}$ & $\begin{array}{l}\text { S III } \\
0.1 \% \\
-75 \%\end{array}$ \\
\hline \multirow{2}{*}{\multicolumn{2}{|c|}{$1^{\text {st }}$ quintile }} & 1,754 & 1,748 & 1,750 & 1,752 \\
\hline & & & $-0.31 \%$ & $-0.23 \%$ & $-0.08 \%$ \\
\hline \multirow{2}{*}{\multicolumn{2}{|c|}{$2^{\text {nd }}$ quintile }} & 7,694 & 7,672 & 7,677 & 7,688 \\
\hline & & & $-0.29 \%$ & $-0.21 \%$ & $-0.07 \%$ \\
\hline \multirow{2}{*}{\multicolumn{2}{|c|}{$3^{\text {rd }}$ quintile }} & 22,890 & 22,832 & 22,846 & 22,875 \\
\hline & & & $-0.25 \%$ & $-0.19 \%$ & $-0.06 \%$ \\
\hline \multirow{2}{*}{\multicolumn{2}{|c|}{$4^{\text {th }}$ quintile }} & 83,909 & 83,495 & 83,599 & 83,805 \\
\hline & & & $-0.49 \%$ & $-0.37 \%$ & $-0.12 \%$ \\
\hline \multirow{2}{*}{\multicolumn{2}{|c|}{$5^{\text {th }}$ quintile }} & $2,403,954$ & $2,396,945$ & $2,398,697$ & $2,402,202$ \\
\hline & & & $-0.29 \%$ & $-0.22 \%$ & $-0.07 \%$ \\
\hline \multirow{2}{*}{\multicolumn{2}{|c|}{ Total }} & $2,520,200$ & $2,512,692$ & $2,514,569$ & $2,518,323$ \\
\hline & & & $-0.30 \%$ & $-0.22 \%$ & $-0.07 \%$ \\
\hline
\end{tabular}

The percentage changes of collateral value should also be evaluated against the background of the figures for over-collateralisation of counterparties that the Eurosystem publishes on a quarterly basis. These figures show that counterparties are on average strongly over-collateralised for a variety of reasons. This allows for the conclusion that the vast majority of counterparties will not suffer a very significant collateral loss due to a transaction cost shock. At the same time, this general statement does not preclude the possibility that single counterparties facing collateral scarceness may experience constraints in their access to central bank liquidity due to a limited collateral pool. This is further highlighted in Annex 5, where we show the impact of transaction costs on two stylised banks with a differing composition of their collateral pools. 


\subsection{Robustness checks}

In order to explore the sensitivity of our results with respect to various assumptions, we conduct two robustness checks. The first robustness check, which was already explained in section 3.4.4, explores the sensitivity of the results to the way in which we compute the turnover ratio in our dataset. In this first robustness check, we do not rely on any trading data but rather assume a turnover ratio of 5 for all assets. Table 13 reproduces Table 7 of the baseline computations for the robustness check. Table 14 directly compares the results of the two computations. The overall effects are very similar, the percentage changes remain constant to the first decimal but there are differences in the absolute values. This underlines that the way in which we use the trading data in our dataset does not lead to disproportionate results.

Table 13: Results of the robustness check 1 (size of second round effects)

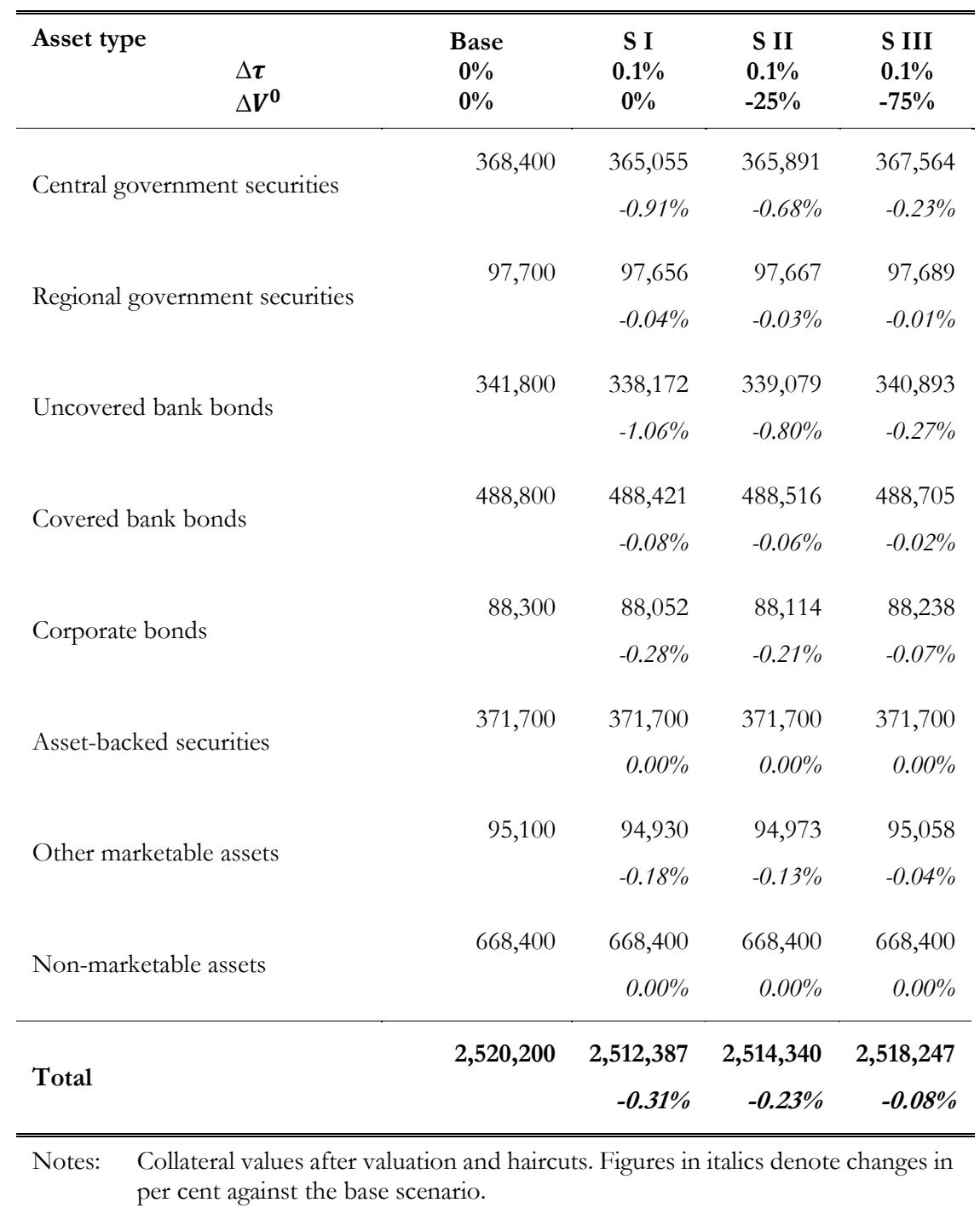


Table 14: Comparison of baseline and robustness check 1

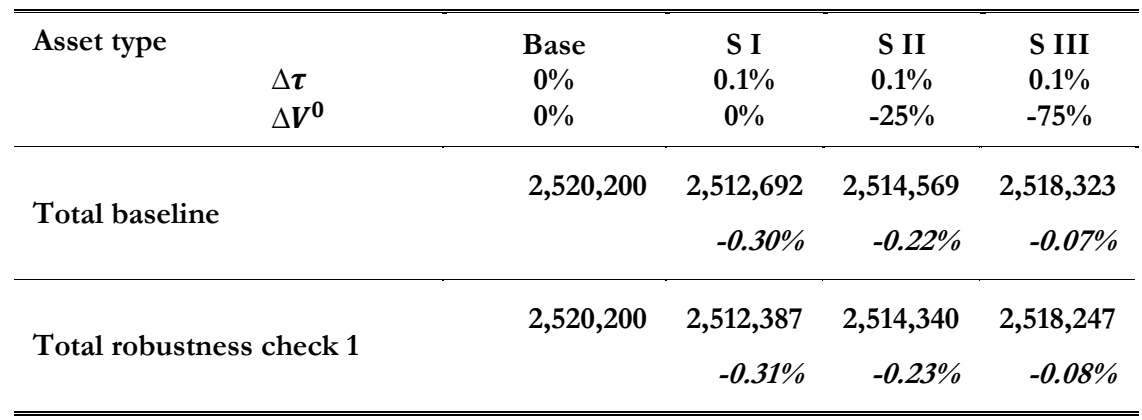

Notes: Collateral values after valuation and haircuts. Figures in italics denote changes in per cent against the base scenario.

As a second robustness check, we present the results for a differently sized transaction cost shock. Table 15 shows the results for a transaction cost shock of $+0.5 \%$.

Table 15: Results of the robustness check 2 (size of transaction cost shock)

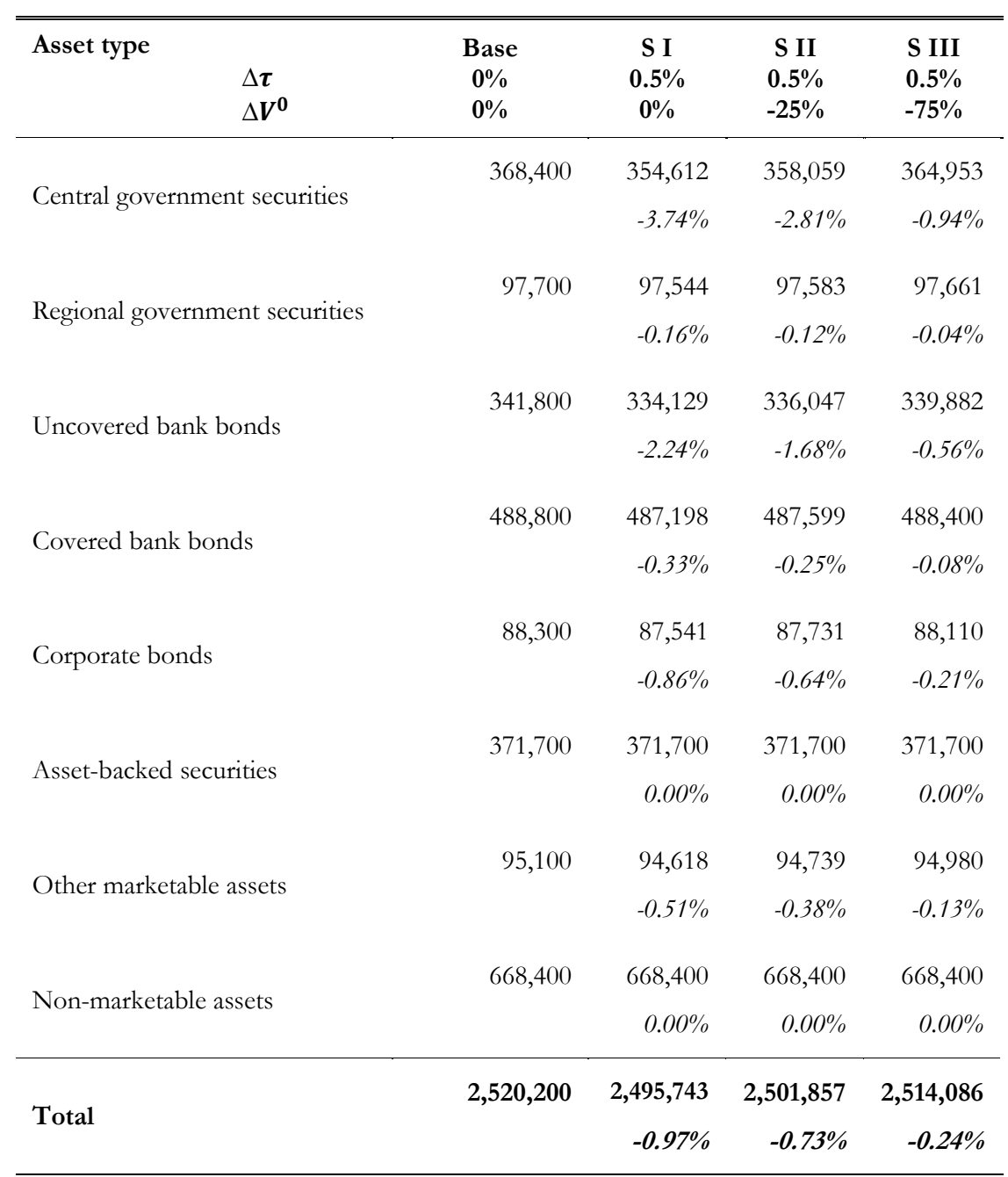

Notes: Collateral values after valuation and haircuts. Figures in italics denote changes in per cent against the base scenario. 
Table 16 compares the totals in the baseline and the robustness check. As expected, the effects are higher when the transaction cost shock is increased to $+0.5 \%$. However, the relationship is not proportional as the effect only increases by roughly three times, while the shock increases five times. The main reason for this is that some collateral assets are assumed not to change their value at all (non-marketable assets and ABS). Therefore, the overall change in collateral value is less than proportional to the transaction cost shock.

Table 16: Comparison of baseline and robustness check 2

\begin{tabular}{|c|c|c|c|c|}
\hline Asset type & $\begin{array}{c}\text { Base } \\
0 \%\end{array}$ & $\begin{array}{l}\text { S I } \\
0 \%\end{array}$ & $\begin{array}{c}\text { S II } \\
-25 \%\end{array}$ & $\begin{array}{l}\text { S III } \\
-75 \%\end{array}$ \\
\hline Total baseline $(\Delta \tau+/-0.1 \%)$ & $2,520,200$ & $\begin{array}{r}2,512,692 \\
-0.30 \%\end{array}$ & $\begin{array}{r}2,514,569 \\
-0.22 \%\end{array}$ & $\begin{array}{r}2,518,323 \\
-0.07 \%\end{array}$ \\
\hline $\begin{array}{l}\text { Total robustness check } 2 \\
(\Delta \tau+/-0.5 \%)\end{array}$ & $2,520,200$ & $\begin{array}{r}2,495,743 \\
-0.97 \%\end{array}$ & $\begin{array}{r}2,501,857 \\
-0.73 \%\end{array}$ & $\begin{array}{r}2,514,086 \\
-0.24 \%\end{array}$ \\
\hline
\end{tabular}

\subsection{Caveats}

This section points out a series of methodological specificities of the study that the reader should keep in mind when interpreting the results that were suggested above. Most importantly one should recall that the dataset reflects a hypothetical banking system. Although the securities are selected from the actual list of eligible assets, the extent of their use by counterparties is based on hypothetical assumptions. This selection procedure could lead to systematic over- or underrepresentation of assets that are most affected by a transaction cost shock due to their turnover or another asset characteristic. This in turn could also bias the aggregate results in either direction.

Another caveat is the incompleteness of the transaction data that we circumvent by cell-mean imputation and scaling up transaction volumes. We have explained previously that the conservative rescaling of transaction volumes implies that the overall simulation results should be interpreted as a lower-bound estimate. For assets, for which we significantly underestimate turnover (for instance ABSs, for which we assume a turnover of zero), the effects may be considerably higher. However, underestimating first-round effects due to missing turnover data also means underestimating the second-round effects on turnover which could partially neutralise the bias.

Another important limitation is our assumption that initial transaction costs are zero, while in practice, many of the assets in our sample have large transaction costs, already driving prices down. This implies that, depending on the current transaction costs for each asset, the impact of any additional shock would be lower than our estimates suggest. 
Furthermore, it should be recalled that the scenarios we use to reflect second-round effects cover a very wide range. The precise estimation of second-round effects on turnover depends on a variety of other variables and a precise estimation goes far beyond the scope of this study. In particular, for short maturities the rise in the yield implied by the price change simulated here suggests that arbitrage trades between short-term debt instruments and other short-term investments such as loans could entail an even higher reduction in turnover. Nevertheless, the scenarios are useful in tracing out the range of possible second effects and the robustness of the results. At the same time, the reader should keep in mind that the scenarios only reflect secondround effects on turnover. Other second-round effects could also affect the price level. For example, a decrease in turnover would also reduce liquidity in certain market segments and hence liquidity premia that investors are willing to pay for such assets. Similarly, it is conceivable that under certain circumstances counterparties optimise their collateral strategies by shifting their pools away from marketable towards more non-marketable assets. This also suggests that the estimates presented in this study are, from this angle, likely at the lower end of true effects.

\section{Concluding remarks and wider implications}

In this study we have shown theoretically and empirically how a transaction cost shock can affect the value of assets that financial institutions use as collateral with their central bank. In the theoretical analysis, we disentangled the various channels through which transaction cost shocks may affect the collateral value and explained how different assets are affected by a transaction cost shock, depending on their turnover, maturity, coupon structure and other characteristics. We also pointed out why financial institutions are affected heterogeneously, conditional on the composition of the collateral they use with the central bank. The theoretical findings were then translated into an asset-by-asset micro-simulation model of the Eurosystem collateral framework. Micro-simulation was chosen because it captures micro heterogeneity at the asset and counterparty level. For this we simulate a dataset with 12,000 assets and 1,800 counterparties and scale the aggregate collateral amounts to the end of quarter 3 of 2012.

We find that a 0.1 percentage point increase in transaction costs entails a $-0.30 \%$ decrease in the value of aggregate collateral when disregarding any second-round effects. At the aggregate level of our hypothetical banking system, the collateral losses are in the order of billions of euros. When taking into account second-round effects on the turnover of debt instruments a $25 \%$ or $75 \%$ decrease in collateral value comes in lower at $-0.22 \%$ and $-0.07 \%$, respectively. When breaking down the results along asset characteristics we find that uncovered bank bonds, central government assets and corporate bonds are most affected with collateral value decreasing by $0.96 \%,-0.91 \%$ and $-0.34 \%$, respectively, in a scenario without second-round effects. Furthermore, maturity buckets with a residual maturity of 3 -to- 5 years and 1 -to- 3 years are more affected $(-0.49 \%$ and $-0.38 \%$ ) than shorter and longer residual maturities. When disentangling the effect for different risk mitigation haircut categories, the results show that the haircut category $5 \%-15 \%$ is affected the most with a $-0.77 \%$ decrease in collateral value.

In a further step we take the analysis from the asset to the counterparty level. Our simulations show that small and large counterparties measured in terms of the value of their collateral pool are 
similarly affected. There is no clear tendency to whether smaller or larger counterparties would be more exposed to a shock in transaction costs.

Overall, the simulation results allow for the conclusion that the vast majority of counterparties will only suffer a small collateral loss due to a transaction cost shock. However, this on-average finding does not exclude that some selected counterparties could suffer larger collateral losses for which they may not be able to compensate if they are collateral-constrained. Thus, on the aggregate level the economic relevance of such an effect is close to zero, or at least a minor concern compared to other potential side effects of the introduction of a transaction cost shock - including intermediation financing costs of companies, etc. It could, however, lead to collateral constraints for individual counterparties.

In this scenario, if counterparties prefer to maintain the size of their collateral buffer after the shock they would have to submit additional collateral. Alternatively, counterparties could tolerate the increased risk of affording a smaller collateral buffer, or reduce their outstanding liquidity position vis-à-vis the Eurosystem. From a policy perspective, assuming counterparties hit their collateral constraint as a result of the transaction cost shock, a small increase in the list of eligible securities for monetary policy operations, or alternatively, a small reduction in the applied haircuts on certain affected assets, would probably be enough to compensate for the shock. 


\section{Annexes}

\section{Annex 1: Dataset description}

\begin{tabular}{|c|c|c|}
\hline Variable & Description & Source \\
\hline Asset type & $\begin{array}{l}\text { Asset type can take on one of the } \\
\text { following specifications: central } \\
\text { government security, regional } \\
\text { government security, uncovered bank } \\
\text { bond, government-guaranteed bank } \\
\text { bond, covered bank bond, corporate } \\
\text { bond, asset-backed security, other } \\
\text { marketable asset, credit claim, cash } \\
\text { deposit, retail mortgage-backed debt } \\
\text { instrument and fixed-term deposit. } \\
\text { These are all asset types eligible as } \\
\text { Eurosystem collateral. }\end{array}$ & ECB list of eligible marketable assets \\
\hline Residual maturity & $\begin{array}{l}\text { Residual maturity assigns the asset to a } \\
\text { certain maturity bucket based on } \\
\text { issuance date and maturity date. }\end{array}$ & ECB list of eligible marketable assets \\
\hline Coupon frequency & $\begin{array}{l}\text { Coupon frequency states whether a } \\
\text { coupon is paid annually, semi-annually } \\
\text { or quarterly }\end{array}$ & ECB list of eligible marketable assets \\
\hline Coupon structure & $\begin{array}{l}\text { Coupon structure distinguishes zero, } \\
\text { variable, fixed and inverse floater } \\
\text { coupons structures. }\end{array}$ & ECB list of eligible marketable assets \\
\hline Coupon rate & $\begin{array}{l}\text { Coupon rate is the interest the coupon } \\
\text { pays at the defined frequency. }\end{array}$ & ECB list of eligible marketable assets \\
\hline Liquidity category & $\begin{array}{l}\text { Liquidity category distinguishes assets } \\
\text { according to their liquidity profiles, } \\
\text { using the Eurosystem's classification for } \\
\text { risk management purposes. According } \\
\text { to this classification, each marketable } \\
\text { asset is allocated to one of five } \\
\text { categories depending on its issuer and } \\
\text { asset type. Category I contains the most } \\
\text { liquid assets, such as central government } \\
\text { and central bank debt instruments, and } \\
\text { category V encompasses asset-backed } \\
\text { securities (ABS). }\end{array}$ & ECB list of eligible marketable assets \\
\hline Price & $\begin{array}{l}\text { Price contains the market price of the } \\
\text { asset as it is used by the Eurosystem to } \\
\text { calculate the value after haircut on the } \\
\text { date of observation. }\end{array}$ & Common Eurosystem Pricing Hub \\
\hline Redemption value & $\begin{array}{l}\text { Redemption value refers to the face } \\
\text { value of the asset. }\end{array}$ & ECB list of eligible marketable assets \\
\hline Haircut & $\begin{array}{l}\text { Haircut contains the variable that is } \\
\text { applied by the Eurosystem when } \\
\text { calculating the collateral value after } \\
\text { haircut. }{ }^{2}\end{array}$ & ECB list of eligible marketable assets \\
\hline Turnover & $\begin{array}{l}\text { Transactions in the secondary market of } \\
50 \text { European exchanges or trading } \\
\text { platforms }\end{array}$ & ECB centralised securities database \\
\hline
\end{tabular}

12 See table 7 of the General Documentation, ibid. 


\section{Annex 2: Illustration of asset price model}

This annex illustrates our simple asset price model based on three exemplary hypothetical bonds. The three bonds $\mathrm{A}, \mathrm{B}$ and $\mathrm{C}$ and their characteristics are pictured in the table. The bonds have a residual maturity of 3 months, 1 year and 10 years respectively. They also differ in their coupon rate. The assumed yield curve is increasing with a moderate slope. The prices in this base scenario are EUR 100.20, EUR 101.00 and EUR 106.75 respectively.

Now suppose the simulation of a transaction cost shock of $+0.1 \%$ with a turnover of the bonds of 5 transactions per year as scenario I. The annual cash flows of the bonds are hence calculated as the difference of the coupon payments and the transaction costs. The transaction costs are the product of the shock times the number of transactions times the average of the price in the base scenario and the redemption value. This average reflects in a very simplified way that the price of the bond converges towards the face value over time. As a consequence of the transaction cost shock, the prices of bonds $A, B$ and C decrease to EUR 100.17, EUR 100.50 and EUR 102.28 respectively. Inversely, the yield to maturity implied by the new price increases for all three securities. What may at first seem counter-intuitive, in reality reflects the higher yield demanded by investors in order to compensate for the lower revenue stream over the life time of the security. The implied yield increases strongly for the short maturities because price changes are hardly discounted over time. No second-round effects are assumed in this scenario.

By contrast, in scenarios II and III we assume a decrease of the number of transactions by $25 \%$ and $75 \%$ as a second-round effect. Hence, the negative cash flow for transaction costs decreases and the respective price and yield shocks become small in comparison to scenario I. In a more complex model, one may want to differentiate the second-round effect across residual maturities with shorter maturities suffering a bigger second round effect. This would, however, reduce the comparability of the effects across maturities, which is the main intention of this example.

\begin{tabular}{|c|c|c|c|c|}
\hline & & Bond A & Bond B & Bond C \\
\hline \multirow[t]{10}{*}{ Base scenario } & Settlement & 18-Jan-14 & 18-Jan-14 & 18-Jan-14 \\
\hline & Maturity & 18-Apr-14 & 18-Jan-15 & 18-Jan-24 \\
\hline & Rate & $1.0 \%$ & $1.5 \%$ & $3.5 \%$ \\
\hline & Redemption & $€ 100$ & $€ 100$ & $€ 100$ \\
\hline & Frequency & 1 & 1 & 1 \\
\hline & Transaction cost shock & $0 \%$ & $0 \%$ & $0 \%$ \\
\hline & No. of trades per annum & 5 & 5 & 5 \\
\hline & Effective annual trades & 1.23 & 5 & 5 \\
\hline & Yield to maturity & $0.20 \%$ & $0.50 \%$ & $2.72 \%$ \\
\hline & Price & $€ 100.20$ & $€ 101.00$ & $€ 106.75$ \\
\hline \multirow{9}{*}{$\begin{array}{l}\text { Scenario I } \\
\text { (first-round effect } \\
\text { only) }\end{array}$} & Transaction cost shock & $0.1 \%$ & $0.1 \%$ & $0.1 \%$ \\
\hline & Effective annual trades & 1.23 & 5 & 5 \\
\hline & Annual cash flow & $€ 0.88$ & $€ 1.00$ & $€ 2.98$ \\
\hline & Coupon payments & $€ 1.00$ & $€ 1.50$ & $€ 3.50$ \\
\hline & Transaction costs & $-€ 0.12$ & $-€ 0.50$ & $-€ 0.52$ \\
\hline & Price & $€ 100.17$ & $€ 100.50$ & $€ 102.28$ \\
\hline & change in price over base & $-0.03 \%$ & $-0.50 \%$ & $-4.19 \%$ \\
\hline & Implied yield to maturity & $0.32 \%$ & $1.00 \%$ & $3.23 \%$ \\
\hline & change in implied yield over base & $61 \%$ & $100 \%$ & $19 \%$ \\
\hline
\end{tabular}




\begin{tabular}{|c|c|c|c|c|}
\hline \multirow{9}{*}{$\begin{array}{l}\text { Scenario II } \\
\text { (first and second- } \\
\text { round effect: } \\
\text { reduction of trade by } \\
25 \% \text { ) }\end{array}$} & Transaction cost shock & $0.1 \%$ & $0.1 \%$ & $0.1 \%$ \\
\hline & Effective annual trades & 0.92 & 3.75 & 3.75 \\
\hline & Annual cash flow & $€ 0.91$ & $€ 1.12$ & $€ 3.11$ \\
\hline & Coupon payments & $€ 1.00$ & $€ 1.50$ & $€ 3.50$ \\
\hline & Transaction costs & $-€ 0.09$ & $-€ 0.38$ & $-€ 0.39$ \\
\hline & Price & $€ 100.18$ & $€ 100.62$ & $€ 103.40$ \\
\hline & change in price over base & $-0.02 \%$ & $-0.37 \%$ & $-3.14 \%$ \\
\hline & Implied yield to maturity & $0.29 \%$ & $0.87 \%$ & $3.10 \%$ \\
\hline & change in implied yield over base & $46 \%$ & $75 \%$ & $14 \%$ \\
\hline \multirow{9}{*}{$\begin{array}{l}\text { Scenario III } \\
\text { (first and second- } \\
\text { round effect: } \\
\text { reduction of trade by } \\
75 \% \text { ) }\end{array}$} & Transaction cost shock & $0.1 \%$ & $0.1 \%$ & $0.1 \%$ \\
\hline & Effective annual trades & 0.31 & 1.25 & 1.25 \\
\hline & Annual cash flow & $€ 0.97$ & $€ 1.37$ & $€ 3.37$ \\
\hline & Coupon payments & $€ 1.00$ & $€ 1.50$ & $€ 3.50$ \\
\hline & Transaction costs & $-€ 0.03$ & $-€ 0.13$ & $-€ 0.13$ \\
\hline & Price & $€ 100.19$ & $€ 100.87$ & $€ 105.63$ \\
\hline & change in price over base & $-0.01 \%$ & $-0.12 \%$ & $-1.05 \%$ \\
\hline & Implied yield to maturity & $0.23 \%$ & $0.62 \%$ & $2.85 \%$ \\
\hline & change in implied yield over base & $15 \%$ & $25 \%$ & $5 \%$ \\
\hline
\end{tabular}

\section{Annex 3: Elasticities of second-round effects}

\begin{tabular}{llcc}
\hline \hline & \multicolumn{2}{l}{ Transaction cost shock -0.1\% } & \\
\hline Transaction cost level & $0.05 \%$ & $0.10 \%$ & $0.50 \%$ \\
\hline Scenario II $(-25 \%)$ & -0.13 & -0.25 & -1.25 \\
Scenario III (-75\%) & -0.38 & -0.75 & -3.75
\end{tabular}

\section{Annex 4: Scaling of market turnover}

Even for the securities in our dataset for which we do observe transactions this data covers a subset of the overall secondary market of these instruments only. In particular, over-the-counter (OTC) transactions are likely to be unobserved in the dataset. While this is a common challenge of transactions data we intend to remedy the resulting bias by scaling up the transaction volumes across the whole dataset by using information from prominent markets for which reliable information on turnover is available. We choose the three biggest secondary debt markets in the euro area (Italy, France and Germany) as reference. The public debt agencies of the three countries regularly publish the outstanding amounts as well as information on secondary market turnover. Based on this information we compute the turnover ratios for the three markets

$$
v_{i, t}^{*}=\frac{V_{i, t}^{*}}{F_{i, t}^{*}},
$$


where $v_{i, t}^{*}$ is the turnover ratio of the debt market of country $i$ in period $t, V_{i, t}^{*}$ denotes turnover of the debt market of country $i$ in period $t$ and $F_{t}$ is the nominal debt outstanding of country $i$ in period $t$, where $t$ is the year 2012. We then compute the turnover ratio based on the trading volume $V_{i, \frac{t}{4}}$ that we observe in our dataset for the period from 1 December 2012 to 1 March 2013 and the nominal debt outstanding of country $i$ that we observe in our dataset at a point in time in the fourth quarter of $2012 F_{i, t}$. We multiply the quarterly transaction volume $V_{i, \frac{t}{4}}$ by four to obtain annual turnover.

$$
v_{i, t}=\frac{4 \times V_{i, \frac{t}{4}}}{F_{i, t}}
$$

Based on these variables we derive a scaling factor for each of the three countries

$$
\sigma_{i}=\frac{v_{i}^{*}}{v_{i}}
$$

The average scaling factor across all three markets is defined as follows

$$
\bar{\sigma}=\frac{\sum_{i}^{D E, F R, I T} \sigma_{i}}{3}
$$

The turnover observed for each single asset in our dataset is then scaled up by $\bar{\sigma}$.

\section{Annex 5: Illustration of counterparty effects}

For better illustration of the effects of a transaction cost change, we show the implications for the collateral pools of two stylised banks A and B. Both banks have a collateral pool of 100 million. Bank A is overweight on central government securities and uncovered bank bonds. Bank B is overweight on nonmarketable assets and asset-backed securities. As a result, the impact for bank $A$ is seven times bigger than for bank B.

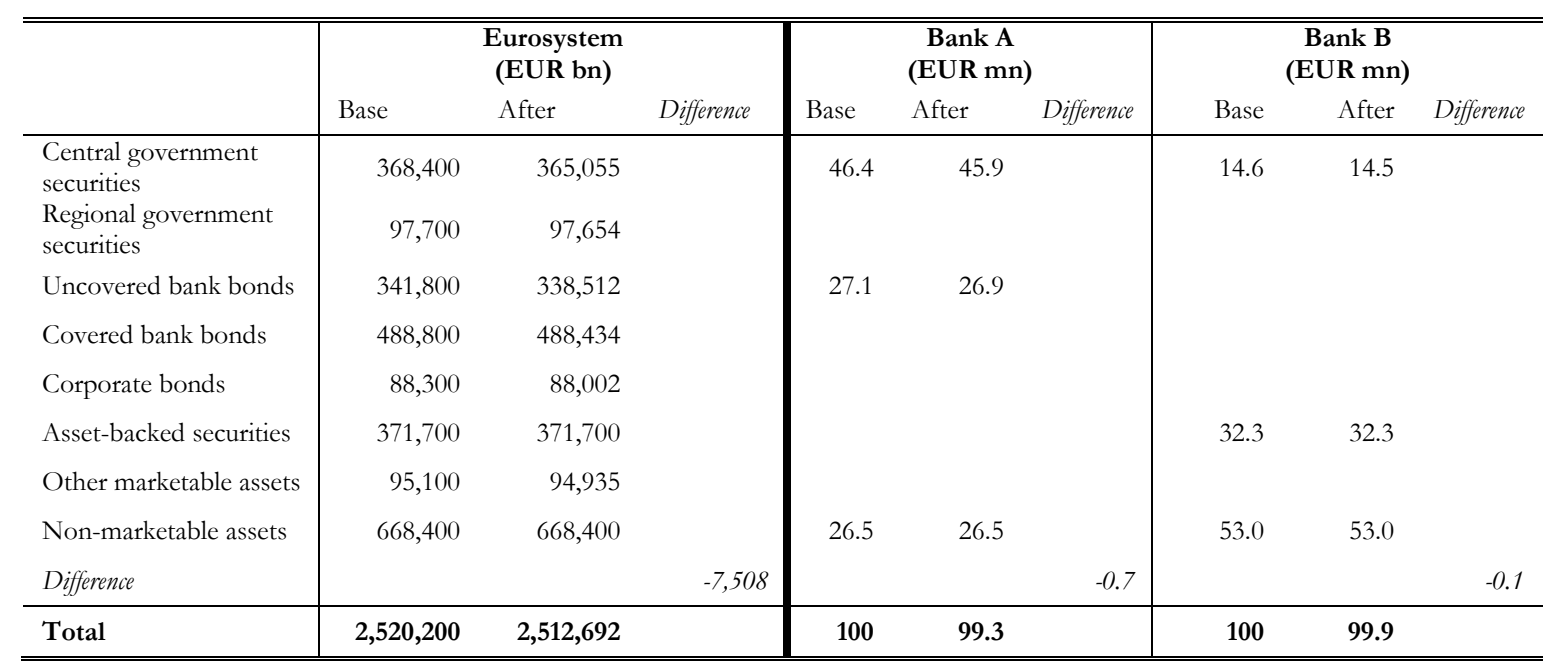




\section{Bibliography}

Acharya, V. V., \& Pedersen, L. H. (2005). Asset pricing with liquidity risk. Journal of Financial Economics, 77(2), 375-410.

Atkins, A. B., \& Dyl, E. A. (1997). Transaction Costs and Holding Periods for Common Stocks. The Journal of Finance, 52(1), 309-325.

Baltagi, B. H., Li, D., \& Li, Q. (2006). Transaction Tax and Stock Market Behavior: Evidence From an Emerging Market. Empirical Economics, 31(2), 393-408.

Block, S. (2007). The Liquidity Discount in Valuing Privately Owned Companies. Journal of Applied Finance, 17(2), 33-40.

Bond, S., Hawkins, M., \& Klemm, A. (2004). Stamp Duty on Shares and its Effect on Share Prices. Institute for Fiscal Studies Working Paper 04/11. London: Institute for Fiscal Studies.

Brorsen, W. (1991). Futures Trading, Transaction Costs, and Stock Market Volatility. The Journal of Futures Markets, 11(2), 153-163.

Campbell, J. Y., \& Froot, K. A. (1994). International Experiences with Securities Transaction Taxes. In J. A. Frankel, The Internationalization of Equity Markets (pp. 277-308). Chicago: University of Chicago Press.

Chalmers, J. M., \& Kadlec, G. B. (1998). An empirical examination of the amortised spread. Journal of Financial Economics, 48(2), 159-188.

Colliard, J.-E., \& Hoffmann, P. (2013). Sand in the Chips? Evidence on Taxing Transactions in Modern Markets.

Constantinides, G. M. (1986). Capital Market Equilibrium with Transaction Costs. The Journal of Political Economic, 94(4), 842-862.

Driessen, J., Melenberg, B., \& Nijman, T. (2005). Testing affine term structure models in case of transaction costs. Journal of Econometrics, 126(1), 204-232.

Dupont, D. Y., \& Lee, G. S. (2007). Effects of securities transaction taxes on depth and bid-ask spreads. Economic Theory, 31, 393-400.

Epps, T. W. (1975). Security Price Changes and Transaction Volumes: Theory and Evidence. American Economic Review, 65(4), 586-597.

Garbade, K. (1982). Securities Markets. New York City: McGraw-Hill.

Hawkins, M., \& McCrae, J. (2002). Stamp Duty on Share Transactions: Is there a Case for Change? The Institute for Fiscal Studies Commentary 89. London: The Institute for Fiscal Studies.

HMRC. (2001). Stamp taxes manual. Retrieved from http://www.hmrc.gov.uk/so/manual.pdf

Hong, G., \& Warga, A. (2000). An Empirical Study of Bond Market Transactions. Financial Analyst Journal, 56(2), 32-46. 
Hu, S.-y. (1998). The effects of the stock transaction tax on the stock market - experiences from Asian markets. Pacific-Basin Finance Journal, 6(3-4), 347-364.

Jarrell, G. A. (1984). SchoolChange at the Exchange: The Causes and Effects of Deregulation. Journal of Law and Economics, 27(2), 273-312.

Keim, D., \& Madhavan, A. (1998). The Cost of Institutional Equity Trades. Financial Analysts Journal, 54(4), 50-69.

Kissell, R. (2006). The Expanded Implementation Shortfall: Understanding Transaction Cost Components. Journal of Trading, 1(3), 6-16.

Kupiec, P. H. (1996). Noise Traders, Excess Volatility, and a Securities Transaction Tax. Journal of Financial Services Reasearch, 10, 115-129.

Kyle, A. (1985). Continuous auctions and insider trading. Econometrica, 53(6), 1315-1335.

Lindgren, R., \& Westlund, A. (1990). How did the Transaction Costs on the Stockholm Stock Exchange Influence Trading Volume and Volatiltiy? Skandinaviska Enskilda Banken Quarterly Review(2), 30-35.

Matheson, T. (2011). Taxing Financial Transactions: Issues and Evidence. IMF Working Paper WP/11/54. Washington, DC: International Monetary Fund.

Oxera. (2007). Stamp duty: its impact and the benefits of its abolition. London: Oxera Consulting Ltd.

Pollin, R., Baker, D., \& Schaberg, M. (2003). Securities transaction taxes for U.S. financial markets. Eastern Economic Journal, 29(4), 527-558.

Pomeranets, A., \& Weaver, D. G. (2011). Security Transaction Taxes and Market Quality. Bank of Canada Working Paper 2011-26. Ottawa: Bank of Canada.

Reiss, P., \& Werner, I. (1996). Transaction Costs in Dealer Markets: Evidence from the London Stock Exchange. In A. W. Lo, The Industrial Organization and Regulation of Securities Industry (pp. 125-169). Chicago: University of Chicago Press.

Roll, R. (1989). Price volatility, international market links, and their implications for regulatory policies. Journal of Financial Services Research, 3(2-3), 211-246.

Saporta, V., \& Kamhon, K. (1997). The effects of stamp duty on the level and volatility of UK equity prices. Bank of England Working Paper 71. London: Bank of England.

Sarr, A., \& Lybek, T. (2002). Measuring Liquidity in Financial Markets. IMF Working Paper WP/02/232. Washington, DC: International Monetary Fund.

Schulmeister, S., Schratzenstaller, M., \& Picek, O. (2008). A General Financial Transaction Tax. Motives, Revenues Feasibility and Effects. Wien: Österreichisches Institut für Wirtschfatsforschung.

Schwert, G. W., \& Seguin, P. J. (1993). Securities Transaction Taxes: An Overview of Costs, Benefits and Unresolved Questions. Financial Analyst Journal, 49(5), 27-35.

Standard and Poor's Corporation. (2012). Global Stock Markets Factbook. New York: Standard \& Poor's corporation. 
Subrahmanyam, A. (1998). Transaction Taxes and Financial Market Equilibrium. Journal of Business, 71(1), $81-118$.

Summers, L., \& Summers, V. (1989). When Financial Markets Work Too Well: A Cautious. Journal of Financial Services Research, 3, 261-286.

Swan, P. L., \& Westerholm, J. (n.d.). The Impact of Transaction Costs on Turnover and Asset Prices: The Cases of Sweden's and Finland's Security Transaction Tax Reductions. (mimeo).

Umlauf, S. (1993). Transaction Taxes and the Behavior of the Swedish Stock Market. Journal of Financial Economics, 227-240.

Wagner, W. H., \& Edwards, M. (1993). Best Execution. Financial Analyst Journal, 49(1), 65-71. 
European Stability Mechanism

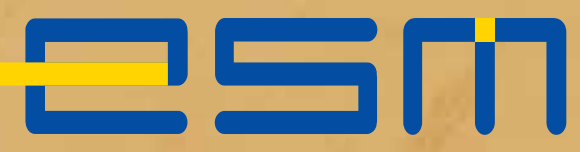

6a Circuit de la Foire Internationale L-1347 Luxembourg

Tel: +352 2602920

www.esm.europa.eu

info@esm.europa.eu 